\title{
Strusky z redukční tavby pelosideritové železné rudy realizované na hradě Buchlově (jv. Chřiby) v roce 2019: extrémní variabilita fázového složení a chemismu jednotlivých fází
}

\author{
Slags from smelting of pelosiderite iron ore realized at the Buchlov Castle \\ (Chřiby Mts., Czech Republic) in 2019: extreme variability of phase composition \\ and chemistry of individual phases
}

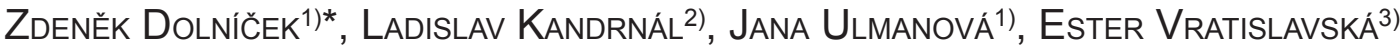 \\ a Pavel HojaČ ${ }^{4}$
}

${ }^{1) M i n e r a l o g i c k o-p e t r o l o g i c k e ́ ~ o d d e ̌ l e n i ́, ~ N a ́ r o d n i ́ ~ m u z e u m, ~ C i r k u s o v a ́ ~ 1740, ~} 19300$ Praha 9;

*e-mail: zdenek.dolnicek@nm.cz

2)Kameňák 145, 69650 Moravany u Kyjova

3)Vlastivědné muzeum, Palackého 70, 69701 Kyjov

4)Komenského 740, 69701 Kyjov

Dolniček Z, Kandrnál L, Ulmanová J, VRatislavská E, Hojač P (2021) Strusky z redukční tavby pelosideritové železné rudy realizované na hradě Buchlově (jv. Chřiby) v roce 2019: extrémní variabilita fázového složení a chemismu jednotlivých fází. Bull Mineral Petrolog 29(1): 59-76 ISSN 2570-7337

\begin{abstract}
During experimental smelting of iron in a replica of historical shaft furnace, which was held at the Buchlov Castle in 2019, charcoal and fresh pelosiderite iron ore from the locality Moravany near Kyjov were used. The obtained furnace slag is practically completely formed by glass phase; only rare small domains contain also crystalline phases, whose occurrence is very irregular. A detailed study of chemical composition showed extreme heterogeneity in composition of glass and most crystalline phases. The glass phase contains variable, but often high amounts of $\mathrm{Mn}, \mathrm{Ca}, \mathrm{Mg}$ and sometimes $\mathrm{P}$ and/or $\mathrm{K}$. The composition of olivine ranges widely among fayalite, dicalciumsilicate and tephroite $\left(\mathrm{Fa}_{1-91}\right.$ $\left.\mathrm{Fo}_{3-28} \mathrm{Te}_{2-45} \mathrm{DCS}_{1-52}\right)$, as well as those of calcic pyroxene $\left(\mathrm{Wo}_{37-60} \mathrm{Tsch}_{1-13} \mathrm{Ka}_{8-22} \mathrm{Fs}_{4-30} \mathrm{En}_{14-36}\right)$. Feldspars showed compositions between orthoclase and anorthite $\left(\mathrm{Or}_{2-82} \mathrm{An}_{9-91} \mathrm{Ab}_{5-19} \mathrm{Cn}_{0-2} \mathrm{Slw}_{0-2}\right)$, which are unknown from natural systems. Minor components include wüstite, melilite (åkermanite with 1-6 mol. \% gehlenite), leucite, kalsilite, locally also apatite and an unnamed phase with composition close to $\mathrm{Ca}_{2} \mathrm{Al}_{2} \mathrm{Si}_{3} \mathrm{O}_{11}$. The produced metallic iron is also compositionally heterogeneous and rich in phosphorus. The phase composition of slag differs significantly from those of typical iron slags. The reason can be seen in anomalous chemical composition of used ore, in too high temperatures during smelting (phase relations in metallic iron suggest temperatures around $1500^{\circ} \mathrm{C}$ ) in combination with rapid cooling of the furnace content after finishing of smelting, and probably also higher viscosity of slag melt. Both phase composition of slag as well as chemical composition of individual slag phases and metallic iron are significantly different from those of local historical artefacts from the period of usage of technology of direct production of iron. These findings do not support the idea that local pelosiderite iron ores were used for production of iron already during this early period.
\end{abstract}

Key words: archaeometallurgy, experimental iron smelting, slags, phosphorus-rich iron, pelosiderite, Chriby Mts.

Obdrženo 18. 2. 2021; prijato 3. 5. 2021

Úvod

V roce 2018 se na nádvoři hradu Buchlov (jv. Chřiby, asi 10 km zsz. od Uherského Hradiště) uskutečnil již 12. ročník Buchlovského kování. $V$ rámci této akce byla $\checkmark$ replice nadzemní šachtové pece, používané $v$ minulosti pro přímou výrobu železa z rud, provedena redukční tavba, při níž byla jako vstupní surovina použita místní pelosideritová a limonitová železná ruda z nedalekého bývalého těženého ložiska Strážovice u Kyjova. Struska a železo, vzniklé při této tavbě, byly podrobněji charakterizovány z pohledu fázového složení a chemického složení jednotlivých fází Dolníčkem et al. (2020). Autoři konstatovali značné rozdíly ve fázovém složení strusky (téměř výhradně tvořena jen sklovinou) i chemickém složení jednotlivých fází (sklovina a fayalit se značně zvýšenými obsahy Mn, kovové železo s vysokým obsahem fosforu) v porovnání s historickými železářskými struskami ze širšího okolí vzniklými v období přímé výroby železa. Autoři se na základě získaných poznatků stavějí skepticky k možnosti, že by mohly být místní pelosiderity a z nich zvětráváním vzniklé limonity již v období prímé výroby železa na Uherskohradišt'sku využívány k výrobě 
železa. Převahu skloviny ve strusce autoři vysvětluji příliš vysokou teplotou $v$ peci $v$ kombinaci s rychlým ochlazením obsahu pece po ukončení tavby, a/nebo specifickým chemickým složením vsázky. V této souvislosti zmiňují vysoké obsahy $\mathrm{Mn}$, které by podle jejich názoru mohly působit jako inhibitor krystalizace; autoři však dodávají, že tuto možnost bude ještě potřeba ověřit dalšími výzkumy.

V červenci 2019 se na Buchlově uskutečnila ve stejném typu pece další experimentální tavba železa, při níž byla použita čerstvá (nezvětralá) pelosideritová železná ruda z jiné nedaleké lokality od Moravan u Kyjova. Bližší mineralogickou charakteristiku zdejší rudy podali Dolníček et al. (2019). Autoři konstatovali prítomnost zvýšených obsahů Mn (klasifikačně odpovídají karbonáty pelosideritů sideritu až Mn-bohatému sideritu) a také i slaběji zvýšených obsahů $\mathrm{Ca}$ a $\mathrm{Mg}$. Strusky z této tavby tedy představují jednak unikátní př́ležitost pro verifikaci hypotéz a závěrů nastíněných při předchozích výzkumech, jednak možnost porovnat, nakolik se budou lišit fázové složení strusky a chemismus jednotlivých fází z tavby, při níž byla použita čerstvá nezvětralá pelosideritová ruda. $Z$ těchto důvodů jsme struskám z této tavby věnovali bližší pozornost.
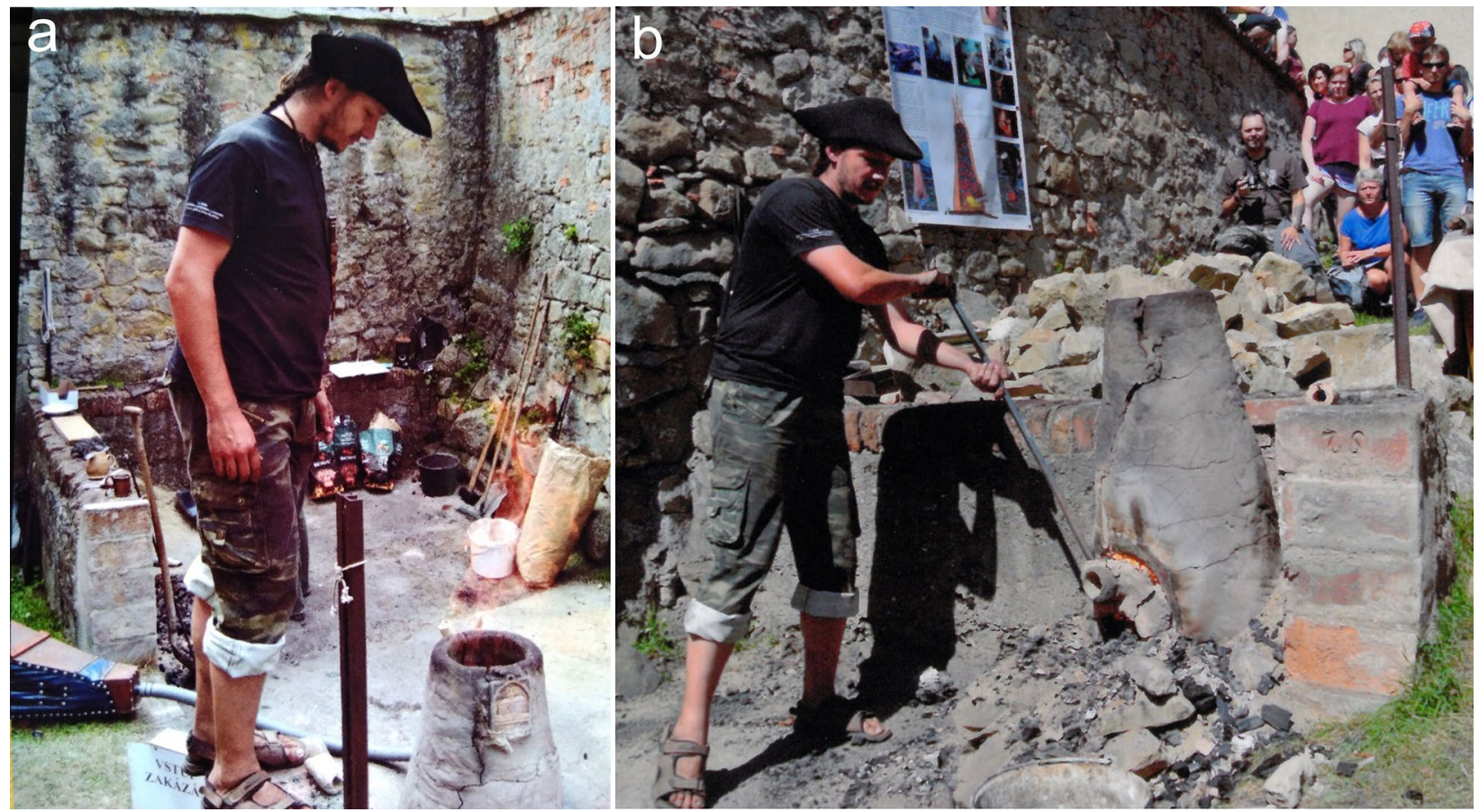

Obr. 1 Tavba železa na hradě Buchlově v roce 2018. a - pec v chodu, vlevo dole měch ke dmýchání větru. b - otvírání pece po ukončení tavby za účelem vylomení nístějového slitku (ilustrační fota P. Hojač).

Tabulka 1 Chemické složení při tavbě použité vypražené rudy (hm. \%, vzhledem k rozdílné porozitě vzorků jsou obsahy normalizovány na sumu 100 \%). PRM-1 - průměrné složení rozpráškovaného vzorku (průměr z osmi analýz, $v$ závorkách uvedena hodnota směrodatné odchylky); PRM-2 - průměrné složení 29 jednotlivých úlomků rudy (průměr z 29 analýz, v závorkách uvedena hodnota směrodatné odchylky); 1 - 11 - př́klady složení jednotlivých úlomků rudy. b.d. - pod mezí stanovitelnosti.

\begin{tabular}{lrrrrrrrrrrrrr}
\hline An. č. & PRM-1 & PRM-2 & 1 & 2 & 3 & 4 & 5 & 6 & 7 & 8 & 9 & 10 & 11 \\
\hline $\mathrm{SO}_{3}$ & $0.20(0.14)$ & $0.09(0.13)$ & b.d. & b.d. & b.d. & b.d. & b.d. & b.d. & b.d. & 0.22 & b.d. & 0.18 & 0.36 \\
$\mathrm{P}_{2} \mathrm{O}_{5}$ & $4.49(0.24)$ & $6.21(11.16)$ & b.d. & b.d. & b.d. & b.d. & b.d. & b.d. & b.d. & b.d. & b.d. & 18.88 & 30.72 \\
$\mathrm{SiO}_{2}$ & $50.51(0.66)$ & $45.08(20.65)$ & 23.48 & 21.60 & 29.69 & 37.31 & 49.56 & 62.20 & 70.31 & 77.65 & 84.86 & 39.91 & 16.73 \\
$\mathrm{TiO}_{2}$ & $0.13(0.08)$ & $0.08(0.18)$ & b.d. & b.d. & b.d. & b.d. & b.d. & 0.17 & b.d. & b.d. & 0.14 & 0.18 & b.d. \\
$\mathrm{Al}_{2} \mathrm{O}_{3}$ & $5.60(0.14)$ & $4.81(1.52)$ & 4.81 & 3.86 & 4.69 & 3.36 & 5.01 & 5.03 & 5.08 & 2.19 & 6.78 & 7.82 & 3.67 \\
$\mathrm{MgO}$ & $1.21(0.28)$ & $1.69(1.79)$ & 1.06 & 5.59 & 3.48 & 4.36 & 3.40 & 1.22 & 0.55 & 0.75 & 0.81 & b.d. & b.d. \\
$\mathrm{CaO}$ & $6.82(0.28)$ & $9.87(15.36)$ & 1.35 & 2.17 & 2.45 & 1.91 & 1.05 & 0.30 & 0.81 & 4.26 & 0.26 & 26.31 & 41.23 \\
$\mathrm{MnO}$ & $1.75(0.09)$ & $1.80(2.09)$ & 0.42 & 4.60 & 3.95 & 5.78 & 2.08 & 1.41 & 0.48 & 0.50 & 0.32 & b.d. & 0.36 \\
$\mathrm{FeO}_{\text {tot }}$ & $27.52(0.68)$ & $28.62(21.55)$ & 67.22 & 61.48 & 54.08 & 47.06 & 37.68 & 28.02 & 21.17 & 13.29 & 5.40 & 3.53 & 1.79 \\
$\mathrm{Na}_{2} \mathrm{O}$ & $0.63(0.21)$ & $0.72(0.52)$ & 1.23 & 0.34 & 1.14 & 0.00 & 0.84 & 0.91 & 1.00 & 0.72 & 0.51 & 1.18 & 2.73 \\
$\mathrm{~K}_{2} \mathrm{O}$ & $0.54(0.06)$ & $0.45(0.24)$ & 0.32 & 0.20 & 0.37 & 0.12 & 0.29 & 0.58 & 0.53 & 0.22 & 0.91 & 0.57 & 0.36 \\
$\mathrm{~F}$ & $0.64(0.04)$ & $0.85(1.49)$ & b.d. & b.d. & b.d. & b.d. & b.d. & b.d. & b.d. & 0.19 & b.d. & 2.49 & 3.56 \\
$\mathrm{Cl}$ & $0.29(0.04)$ & $0.12(0.11)$ & 0.13 & 0.20 & 0.20 & 0.12 & 0.11 & 0.22 & 0.10 & 0.11 & b.d. & b.d. & b.d. \\
$\mathrm{O}=\mathrm{F}+\mathrm{Cl}$ & -0.34 & -0.38 & -0.03 & -0.05 & -0.05 & -0.03 & -0.02 & -0.05 & -0.02 & -0.11 & 0.00 & -1.05 & -1.50 \\
\hline $\mathrm{Celkem}$ & 100 & 100 & 100 & 100 & 100 & 100 & 100 & 100 & 100 & 100 & 100 & 100 & 100 \\
\hline
\end{tabular}




\section{Tavba železa na Buchlově 2019}

Pro tavbu byla použita místní železná ruda, získaná autory tohoto příspěvku na dochované rudní haldičce opuštěného malého ložiska pelosideritů Koryčanská cesta u Moravan, těženého v polovině 19. století pro potřeby hutě ve Strážovicích u Kyjova (Dolníček et al. 2019). Nasbírané nezvětralé konkrece pelosideritu měly šedou, při povrchu místy slabě narezlou barvu a velikost maximálně $20 \mathrm{~cm}$. Ruda byla v předstihu před tavbou vypražena na otevřeném ohni (Barák 1995). Kusy rudy byly naskládány na hromadu, kolem níž byla postavena hranice $z$ bukových polen. Po vyhoření hranice a vychladnutí byla vypražená ruda ručně nadrcena na frakci kolem $2-5 \mathrm{~mm}$.

Pro potřeby experimentální tavby byla v předstihu zhotovena replika nadzemní šachtové pece (obr. 1). Pec, dyznový panel i dyzna byly zhotoveny z průmyslové šamotové hlíny. Vzduch byl do pece dmýchán pomocí měchu o objemu cca 100 - 150 I (obr. 1a); dmýchání větru bylo spíše mírné a probíhalo po celou dobu tavby, s krátkými pauzami při přisazování uhlí a rudy. Jako palivo bylo použito komerčně dostupné bukové a dubové dřevěné uhlí. Ruda a dřevěné uhlí byly po vysušení a předehřátí pece $(3 \mathrm{~h})$ prisazovány $\mathrm{v}$ hmotnostním poměru $1: 1 \mathrm{v}$ celkem 20 dávkách v 5 - 10-minutových intervalech (celková doba chodu pece $s$ přisazováním rudy a uhlí činila 2.5 hodiny). Celkem bylo do pece vsazeno cca 15 - 20 kg vypražené rudy. Během tavby nebyly do vsázky přidávány žádné další struskotvorné či jiné přísady. Po vsazení vší připravené rudy byl učiněn pokus o odpuštění strusky, který však nebyl úspěšný (žádná kapalná struska neodtekla). Poté bylo pokračováno další 1.5 hodiny $v$ tavbě pouze $s$ přisazením 1 dávky uhlí. Po vyhoření většiny vsazeného obsahu pece byl učiněn další pokus o odpuštění strusky, který byl opět neúspěšný. Následně byl odstraněn dyznový panel (obr. 1b) a z pece byl ještě za žhava vylomen nístějový struskový slitek, který však obsahoval pouze stopy vyredukovaného železa.

\section{Materiál a metodika}

Nábrusy ze studovaných strusek a použité rudy byly zhotoveny zalitím odřezků vzorků do epoxidové pryskyřice a naleštěním pomocí diamantových suspenzí. Průmèrný práškový vzorek použité rudy byl připraven rozetřením na analytickou jemnost $v$ achátové třecí misce, mírně zvlhčen epoxidovou pryskyřicí a rovněž zalit do téže pryskyřrice a naleštěn. Dokumentace nábrusů $v$ odraženém světle byla provedena na odrazovém polarizačním mikroskopu Nikon Eclipse ME600. Následně byly preparáty potaženy uhlíkovým filmem o tloušt'ce $30 \mathrm{~nm}$ a studovány na elektronové mikrosondě Cameca SX-100 v laboratoři Mineralogicko-petrologického oddělení Národního muzea v Praze. Na přístroji byly pořízeny snímky ve zpětně odražených elektronech (BSE), provedena identifikace jednotlivých fází pomocí energiově disperzních (EDS) spekter a kvantitativně měřeno chemické složení vybraných fází ve vlnově disperzním (WDS) modu. Analýzy skloviny a jednotlivých „minerálních“ fází byly provedeny jako analýzy bodové, za použití urychlovacího napětí $15 \mathrm{kV}$, fokusovaného elektronového svazku o průměru cca 0.7 $\mu \mathrm{m}$ a proudu svazku 20 nA. Celkové chemické složení kovových kapek bylo měřeno za stejných podmínek jako jednotlivé bodové analýzy, při analýze však byl snímán signál z co největší plochy dané kapky, aniž by ovšem byla zahrnuta i struska. Analýzy použité rudy byly měřeny z plochy o rozměrech cca $1500 \times 1200 \mu \mathrm{m}$ při $15 \mathrm{kV}$ a
10 nA. Ve všech analýzách skloviny, melilitu, pyroxenu, olivínu a použité železné rudy byly měřeny obsahy $\mathrm{Al}, \mathrm{Ba}$, $\mathrm{Ca}, \mathrm{Cl}, \mathrm{Cr}, \mathrm{F}, \mathrm{Fe}, \mathrm{K}, \mathrm{Mg}, \mathrm{Mn}, \mathrm{N}, \mathrm{Na}, \mathrm{Ni}, \mathrm{P}, \mathrm{S}, \mathrm{Si}, \mathrm{Sr}, \mathrm{Ti}, \mathrm{V}$, $\mathrm{Zn}$ a $\mathrm{Zr}$, ve wüstitu a železe obsahy $\mathrm{Al}, \mathrm{Ca}, \mathrm{Co}, \mathrm{Cr}$, $\mathrm{Fe}$, $\mathrm{Mg}, \mathrm{Mn}, \mathrm{Ni}, \mathrm{P}, \mathrm{S}, \mathrm{Si}, \mathrm{Ti}, \mathrm{V}, \mathrm{Zn}$ a Zr, v apatitu obsahy Al, As, $\mathrm{Ba}, \mathrm{Ca}, \mathrm{Ce}, \mathrm{Cl}, \mathrm{F}, \mathrm{Fe}, \mathrm{K}, \mathrm{Mg}, \mathrm{Mn}, \mathrm{Na}, \mathrm{P}, \mathrm{Pb}, \mathrm{S}, \mathrm{Si}, \mathrm{Sr}$, Y a Zn a $v$ živcích, leucitu, kalsilitu a $v$ nepojmenované Ca-Al-Si fázi obsahy $\mathrm{Al}, \mathrm{Ba}, \mathrm{Ca}, \mathrm{Cs}, \mathrm{Cu}, \mathrm{Fe}, \mathrm{Mg}, \mathrm{Mn}, \mathrm{N}, \mathrm{K}$, $\mathrm{Na}, \mathrm{P}, \mathrm{Pb}, \mathrm{Rb}, \mathrm{Si}, \mathrm{Sr}$ a $\mathrm{Zn}$. Použité analytické čáry a stan-

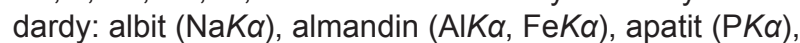
baryt $(\mathrm{Ba} L \alpha), \mathrm{BN}(\mathrm{N} K \alpha)$, celestin $(\mathrm{Sr} L \beta, \mathrm{S} K \alpha), \mathrm{CePO}_{4}$ (CeL $\alpha)$, $\mathrm{Co}(\mathrm{CoK} \alpha), \mathrm{Cr}_{2} \mathrm{O}_{3}(\mathrm{Cr} K \alpha)$, Cs-sklo (CsL $\left.\alpha\right)$, diopsid $(\mathrm{Mg} K \alpha)$, halit $(\mathrm{Cl} K \alpha)$, hematit $(\mathrm{Fe} K \alpha)$, chalkopyrit (CuKa), klinoklas (As $L \beta)$, LiF (FKa), Ni (NiKa), Rb-Ge sklo (RbLa), rodonit $(\mathrm{Mn} K \alpha)$, sanidin $(\mathrm{K} K \alpha, \mathrm{Si} K \alpha, \mathrm{Al} K \alpha), \mathrm{TiO}_{2}(\mathrm{Ti} K \alpha), \mathrm{V}$ $(\mathrm{VK} \alpha)$, vanadinit $(\mathrm{Pb} M \alpha)$, wollastonit $(\mathrm{CaK} \alpha, \mathrm{Si} \alpha), \mathrm{YVO}_{4}$ $(\mathrm{Y} L \alpha)$ a zinkit $(\mathrm{ZnK \alpha})$. Měřící časy na píku se pohybovaly mezi 10 a $30 \mathrm{~s}$ (pro dusík $150 \mathrm{~s}$ ), měřící časy pozadí trvaly polovinu času měření na píku. Načtená data byla přepočítána na hm. \% s použitím standardní PAP korekce (Pouchou, Pichoir 1985). Obsahy měřených prvků, které nejsou uvedeny $v$ níže uvedených tabulkách, byly ve všech prípadech pod mezí stanovitelnosti.

\section{Charakteristika použité rudy}

Vzhledem $\mathrm{k}$ tomu, že mineralogickou charakteristikou pelosideritů z lokality Moravany se podrobně zabývali již Dolníček et al. (2019), zaměřili jsme se v rámci této práce hlavně na charakterizaci chemického složení pro tavbu použité vypražené rudy. Makroskopicky mají úlomky vypražené rudy červenohnědou barvu. Již při zběžném vizuálním posouzení Ize u různých úlomků konstatovat značné rozdíly $v$ zrnitosti a $v$ obsahu písčité príměsi, což potvrdilo i studium v odrazovém mikroskopu. Celkové chemické složení bylo zjišt'ováno jednak na rozpráškovaném reprezentativním vzorku rudy, jednak na jednotlivých samostatných úlomcích rudy - $v$ druhém prípadě $s$ cílem postihnout míru variability $v$ chemismu. Tyto analýzy ukázaly, že variabilita $v$ chemismu jednotlivých úlomků je velice široká (tab. 1, analýzy 1 - 11). Analýzy s nejvyššími obsahy Fe představují pelosiderity s relativně nízkým obsahem siliciklastické př́měsi, opačným extrémem je analýza č. 9 , reprezentující z pohledu chemismu běžný místní pískovec, nebo analýzy č. 10 a 11, odpovídající fosforitům se siliciklastickou príměsí (srov. Dolníček et al. 2019). Velice široká variabilita $v$ chemismu jednotlivých úlomků rudy je ilustrována také vysokými hodnotami směrodatné odchylky, které jsou u poloviny měřených oxidů dokonce vyšší, než vypočítaný průměrný obsah oxidu (tab. 1, sloupec PRM-2). Rozpráškovaný průměrný vzorek použité rudy ukázal rámcově podobné složení (tab. 1, sloupec PRM-1) jako průměr vypočítaný $z$ analýz jednotlivých úlomků, ovšem při nesrovnatelně menší variabilitě datového souboru.

\section{Charakteristika strusek}

Bliže studováno bylo sedm vzorků strusek. Vzorky dosahují velikosti až $10 \times 15 \mathrm{~cm}$ (obr. 2). Ve všech prípadech jde o úlomky větších kusů. Na některých vzorcích je zachovaný původní, silně nerovný povrch, vyznačující se intenzivním skelným, někdy i polokovovým leskem. Část vzorků má hladký povrch a krápníkovitý tvar (obr. 2b). Na čerstvém lomu jsou všechny strusky černé, černozelené až špinavě zelené, sklovitého vzhledu. Na povrchu maji strusky někdy připečená křemenná zrna. Všechny vzor- 

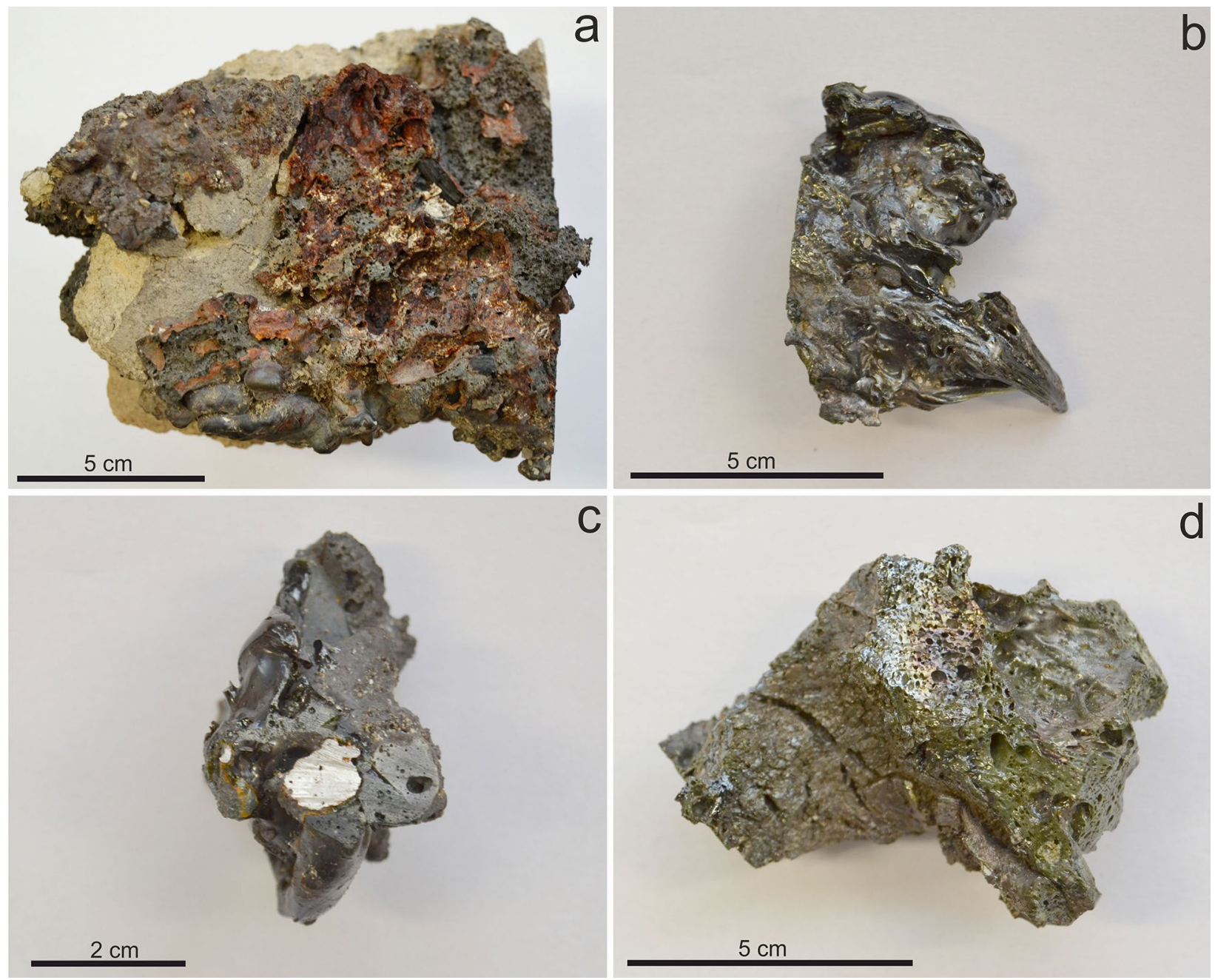

Obr. 2 Makroskopický vzhled studovaných vzorků. a - vzorek STR-9, nístějová struska s vyredukovaným železem (rezavé) a pripečeným konstrukčním materiálem pece (béžový). b - vzorek STR-12, sklovitá skelně lesklá krápníkovitá struska. c - vzorek STR-10, struska s kapkou železa na přícném řezu vzorkem. d - vzorek STR-6, zelenavá sklovitá bublinatá struska, místy s polokovovým leskem. Snímky J. Ulmanová.

Tabulka 2 Fázové složení (hemi)krystalických domén ve studovaných struskách a variabilita chemismu jednotlivých fází. n.d. - nestanoveno

\begin{tabular}{|c|c|c|c|c|}
\hline Poř.č. & Vzorek & Velikost & Hlavní fáze & Vedlejší a akcesorické fáze \\
\hline 1 & STR-10 & $0.4 \mathrm{~mm}$ & $\begin{array}{l}\text { pyroxen }\left(\mathrm{Wo}_{37-41} \mathrm{Tsch}_{1-4} \mathrm{Ka}_{14-15} \mathrm{Fs}_{28-30} \mathrm{En}_{14-18}\right) \\
\text { živce }\left(\mathrm{Or}_{19-82} \mathrm{An}_{9-64} \mathrm{Ab}_{9-19} \mathrm{Cn}_{0-1}\right)\end{array}$ & olivín $\left(\mathrm{Fa}_{68-71} \mathrm{Fo}_{13-16} \mathrm{Te}_{11-13} \mathrm{DCS}_{3}\right)$ \\
\hline 2 & STR-10 & $0.6 \mathrm{~mm}$ & sklo bohaté Ca a P & apatit \\
\hline 3 & STR-10 & & pyroxen II $\left(\mathrm{Wo}_{48-60} \mathrm{Tsch}_{1-3} \mathrm{Ka}_{17-22} \mathrm{Fs}_{4-7} \mathrm{En}_{18-22}\right)$ & $\begin{array}{l}\text { pyroxen I }\left(\mathrm{Wo}_{45-47} \mathrm{Tsch}_{6-13} \mathrm{Ka}_{8-11} \mathrm{Fs}_{4-7} \mathrm{En}_{25-36}\right) \\
\text { olivín }\left(\mathrm{Fa}_{29-35} \mathrm{Fo}_{12-23} \mathrm{Te}_{23-28} \mathrm{DCS} \mathrm{S}_{18-33}\right) \\
\text { živce }\left(\mathrm{Or}_{2-76} \mathrm{An}_{17-91} \mathrm{Ab}_{5-7} \mathrm{Cn}_{0-2} \mathrm{Slw}_{0-2}\right) \\
\text { nepojmenovaná Ca-Al-Si fáze }\end{array}$ \\
\hline & & & & leucit, místy sklo bohaté Ca a P \\
\hline $4 a$ & STR-9 & n.d. & $\begin{array}{l}\text { olivín jádro }\left(\mathrm{Fa}_{62-63} \mathrm{Fo}_{22-24} \mathrm{Te}_{2-3} \mathrm{DCS}_{11-13}\right) \\
\text { olivín okraj }\left(\mathrm{Fa}_{66-69} \mathrm{Fo}_{3} \mathrm{Te}_{2} \mathrm{DCS}_{27-29}\right)\end{array}$ & wüstit, železo, sklo \\
\hline $4 \mathrm{~b}$ & STR-9 & n.d. & $\begin{array}{l}\text { olivín jádro }\left(\mathrm{Fa}_{42-49} \mathrm{Fo}_{3-9} \mathrm{Te}_{2} \mathrm{DCS}_{45-47}\right) \\
\text { kalsilit, železo bez } \mathrm{P}\end{array}$ & $\begin{array}{l}\text { olivín okraj }\left(\mathrm{Fa}_{88} \mathrm{Fo}_{3} \mathrm{Te}_{3} \mathrm{DCS}_{6}\right) \\
\text { wüstit, sklo bohaté } \mathrm{K}\end{array}$ \\
\hline $4 c$ & STR-9 & n.d. & $\begin{array}{l}\text { olivín jádro }\left(\mathrm{Fa}_{30-58} \mathrm{Fo}_{12-20} \mathrm{Te}_{2} \mathrm{DCS}_{19-52}\right) \\
\text { olivín okraj }\left(\mathrm{Fa}_{58-69} \mathrm{Fo}_{1-9} \mathrm{Te}_{2} \mathrm{DCS}_{26-34}\right)\end{array}$ & sklo, železo \\
\hline 5 & STR-11 & $0.4 \mathrm{~mm}$ & melilit, sklo & \\
\hline 6 & STR-12 & $0.1 \mathrm{~mm}$ & olivín $\left(\mathrm{Fa}_{1} \mathrm{Fo}_{27-28} \mathrm{Te}_{35-45} \mathrm{DCS}_{28-37}\right)$ & sklo \\
\hline 7 & STR-12 & $0.1 \mathrm{~mm}$ & $\begin{array}{l}\text { olivín střed }\left(\mathrm{Fa}_{41-46} \mathrm{Fo}_{12-15} \mathrm{Te}_{2} \mathrm{DCS}_{38-41}\right) \\
\text { olivín okraj }\left(\mathrm{Fa}_{60-66} \mathrm{Fo}_{14-19} \mathrm{Te}_{6-10} \mathrm{DCS}_{11-14}\right)\end{array}$ & wüstit \\
\hline 8 & STR-12 & $0.5 \mathrm{~mm}$ & olivín $\left(\mathrm{Fa}_{89-91} \mathrm{Fo}_{4-7} \mathrm{Te}_{3} \mathrm{DCS}_{1-2}\right)$ & sklo \\
\hline
\end{tabular}


ky mají lasturnatý lom a $v$ tenkých třískách někdy zeleně prosvítají. Jsou také silně porézní - porozita je z větší části způsobena hojnými okrouhlými bublinami variabilní velikosti (max. až přes $2 \mathrm{~cm}$ ), v menší míře i uzavřeninami dřevěného uhlí (velikost až $2 \mathrm{~cm}$ ), které je ve vzorcích zčásti dochované, místy vyhořelé či vydrolené. S výjim- kou největšího kusu (STR-9), který představuje úlomek nístějové strusky $s$ malým množstvím vyredukovaného kovu a úlomkem vyzdívky pece (obr. 2a), vzorky strusek prakticky nereagují na permanentní feritový magnet. Zcela ojediněle byly zaznamenány i makroskopicky viditelné sférické kapky kovu uložené ve sklovité matrici (obr. 2c).
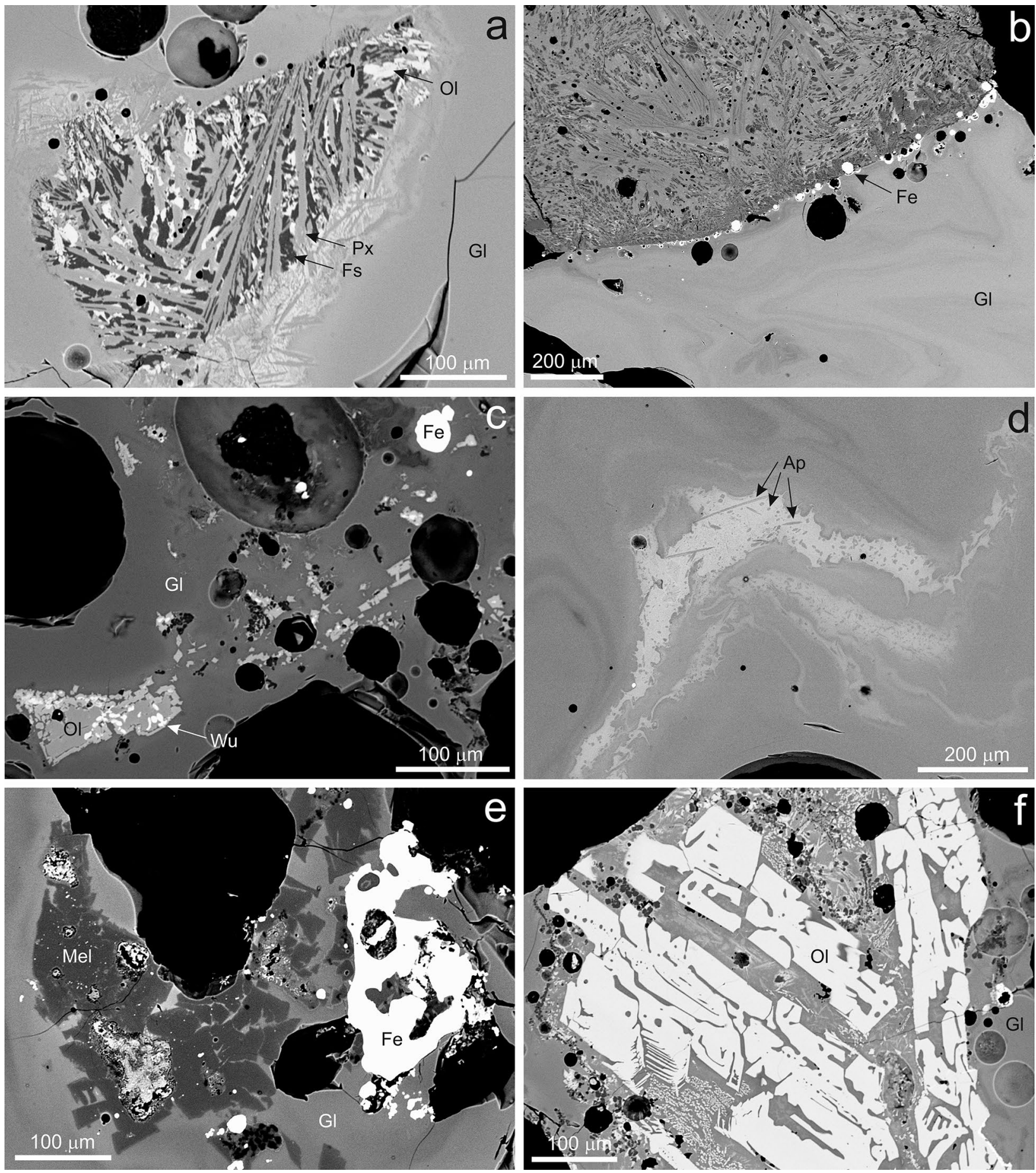

Obr. 3 Stavba a fázové složení studovaných strusek na BSE snímcích. a - ostře omezená krystalická doména č. 1, tvořená lištovitým pyroxenem (Px), olivínem (OI) a K-Ca živcem (Fs), uložená ve skle (GI), které vykazuje na kontaktu s krystalickou doménou devitrifikaci. Vzorek STR-10. b - ostrý kontakt krystalické domény č. 3 s okolním sklem (GI) vzorku STR-10. Kontakt je lemován drobnými kuličkami kovového železa (Fe). c - neostře omezená doména č. 7 , tvořená krystaly olivínu (OI, světlejši nárůsty jsou bohatší fayalitovou složkou) s uzavřeninami wüstitu (Wu), vzorek STR-12. Fe - kovové železo. d-neostře omezená doména č. 2, tvořená jehlicovitými krystaly apatitu (Ap) uloženými ve fosforem bohaté sklovině (světlá), tvořici smouhu ve fosforem chudé sklovině (tmavší). Vzorek STR-10. e - doména č. 5, tvořená krystaly melilitu (Mel) ve sklovině (GI) v sousedství částice kovového železa (Fe), vzorek STR-11. f-doména č. 8, tvořená dvěmi generacemi olivínu (Ol) ve sklovině (GI), vzorek STR-12. Všechny snímky Z. Dolníček. 
Podrobnější studium nábrusů ukázalo velmi jednoduché fázové složení strusek vzorků STR-6, -7 a -8, které jsou tvořeny jen sklem $s$ ojedinělými drobnými kapkami kovového železa. Vzorky STR-9, -10, -11 a -12 jsou z velké části rovněž tvořeny sklovinou $s$ ojedinělými kapkami železa, lokálně však obsahují i drobné domény s krystalickou či hemikrystalickou strukturou. Tyto domény jsou vůči okolní sklovině většinou ostře omezené (obr. 3a,b), mají ostrohranný tvar a velikost většinou v rozmezí 0.5 $\mathrm{cm}$ až $0.1 \mathrm{~mm}$. Ve dvou prípadech jsou domény dlouze protažené ve směru toku skloviny, přičemž jsou tvořeny jednotlivými rozvlečenými krystaly krystalických fází izolovaně uzavřených ve skle (obr. 3c,d). V případě vzorku nístějové strusky STR-9 přesáhla velikost hemikrystalické domény velikost nábrusu, takže její velikost nelze přesně specifikovat. $V$ jediném prípadě byla $v$ exokontaktu krystalické domény pozorována devitrifikace okolního skla do vzdálenosti $100 \mu \mathrm{m}$ (obr. 3a). Polovina zjištěných domén (4 ks) obsahuje vedle skla jen jedinou krystalickou fázi, jíž je olivín, apatit, či melilit (tab. 2, obr. 3d-f). Ve dvou př́padech jsou tyto jednofázové domény představovány jen jediným krystalem. Další doména obsahuje vedle olivínu i malé množství wüstitu (obr. 3c). Zbylé tři domény jsou minimálně trífázové a na jejich složení se podílí olivín, pyroxen, wüstit, živec, leucit, kalsilit, nepojmenovaná Ca-Al-Si fáze, železo a sklovina (obr. 3a,b; tab. 1). Doména č. 4 ze vzorku STR-9 (nístějová struska) ukázala velmi rozdílná složení v různých částech; v tabulce 2 jsou jednotlivé části této domény označeny písmeny a-c. Součástí všech vzorků strusek jsou i neroztavené relikty zrn křemene a zcela ojediněle i zirkon (STR-6).

Sklovina je zcela převažující fází ve všech studovaných vzorcích strusek. V BSE obraze je charakteristicky patrná její nehomogenní stavba (obr. 3). Časté jsou fluidální textury, vzniklé tečením roztaveného materiálu, dobře viditelné díky rozdílům $v$ chemickém složení jednotlivých proužků skloviny (obr. 3b,d). Kolem korodovaných zrn křemene se charakteristicky vyskytují tmavší (v obraze BSE) lemy, tvořené sklovinou s vyšším obsahem $\mathrm{SiO}_{2}$. I při velkém zvětšení je sklovina většinou homogenní, nedevitrifikovaná, lokálně s obsahem mikroskopických kulovitých kapiček vyredukovaného kovu. Devitrifikace skla byla pozorována pouze ojediněle $v$ exokontaktu holokrystalické domény č. 1 , v lemu mocném maximálně 0.1 $\mathrm{mm}$ (obr. 3a).

Podrobně bylo studováno chemické složení skloviny. Celkem bylo pořizeno 60 bodových WDS analýz ze všech sedmi studovaných vzorků. Reprezentativní výběr analýz je uveden $v$ tabulce 3 a graficky jsou variace $v$ chemismu skloviny ilustrovány na obrázku 4. Variabilita celého získaného datového souboru je značně široká. Obsahy $\mathrm{SiO}_{2}$ se pohybují mezi 25.4 a $71.5 \mathrm{hm}$. \% (pomineme-li šest odlehlých hodnot, pohybuji se ve výrazně užším intervalu mezi 40 a 50 hm. \%), FeO $2.5-31.1$ hm. \%, $\mathrm{Al}_{2} \mathrm{O}_{3} 1.6$ 19.7 hm. \%, CaO 1.9 - 24.0 hm. \%, MgO 0.0 - 4.7 hm. \%, $\mathrm{MnO} 0.2$ - 9.3 hm. \%, $\mathrm{BaO} 0.0$ - 0.5 hm. \%, $\mathrm{Na}_{2} \mathrm{O} 0.2$ - 1.9 hm. \%, $\mathrm{K}_{2} \mathrm{O} 0.6-11.1 \mathrm{hm} . \%, \mathrm{P}_{2} \mathrm{O}_{5} 0.1-16.7 \mathrm{hm} . \%, \mathrm{TiO}_{2}$ $0.1-0.6 \mathrm{hm}$. \%, $\mathrm{SO}_{3} 0.0-3.5 \mathrm{hm}$. \%. Pozoruhodné jsou zvýšené obsahy fluoru, které se pohybují mezi 0.0 a 1.4 hm. \%.

Olivín je jedinou nebo převažující silikátovou krystalickou fází v polovině zjištěných (hemi)krystalických domén (č. 4 a 6 - 8; tab. 2), zatímco v ostatních bud' chybí, nebo je prítomen jen $v$ podružném množství. Krystaly olivínu dosahují velikosti až $0.7 \mathrm{~mm}$. Mají tlustě tabulkovitý či izometrický tvar a automorfní až xenomorfní omezení (obr. 3c,f, 5a-d). Kostrovité krystaly jsou vzácné a prakticky výhradně náleží druhé generaci olivínu, místy přítomné v drobných individuích ve sklovině mezerní hmoty některých (hemi)krystalických domén (obr. 3f, 5b). Typickým jevem je též prrítomnost inkluzí či „zálivư“ skla v krystalech olivínu (obr. 3f, 5a). Méně často jsou v olivínech uzavírány drobné inkluze wüstitu, kovového železa či kalsilitu (obr. 5a-d). V BSE obraze Ize konstatovat prípad od případu odlišnou vnitřní stavbu olivínových krystalů. V polovině (hemi)krystalických domén jsou olivíny nezonální, zatímco $v$ druhé polovině vzorků lze pozorovat jednoduchou zonálnost, kdy v BSE obraze tmavší jádro postupně (difuzně) přechází ve světlejší okraj (obr. 5a,b).

Chemické složení olivínu bylo podrobně studováno prostřednictvím 70 bodových WDS analýz, jejichž reprezentativní výběr je prezentován $v$ tabulce 4 . Všechny získané analýzy jsou prezentovány $v$ grafické podobě (obr. $6 a-c, 7 a)$. Stechiometrie této fáze je většinou velmi dobrá;

Tabulka 3 Přiklady chemického složení skloviny. Obsahy oxidů v hm. \%. M - medián z 60 bodových analýz, 1 - 13 jednotlivé bodové analýzy, v.i. - index viskozity dle Bachmana (1982). b.d. - pod mezí stanovitelnosti

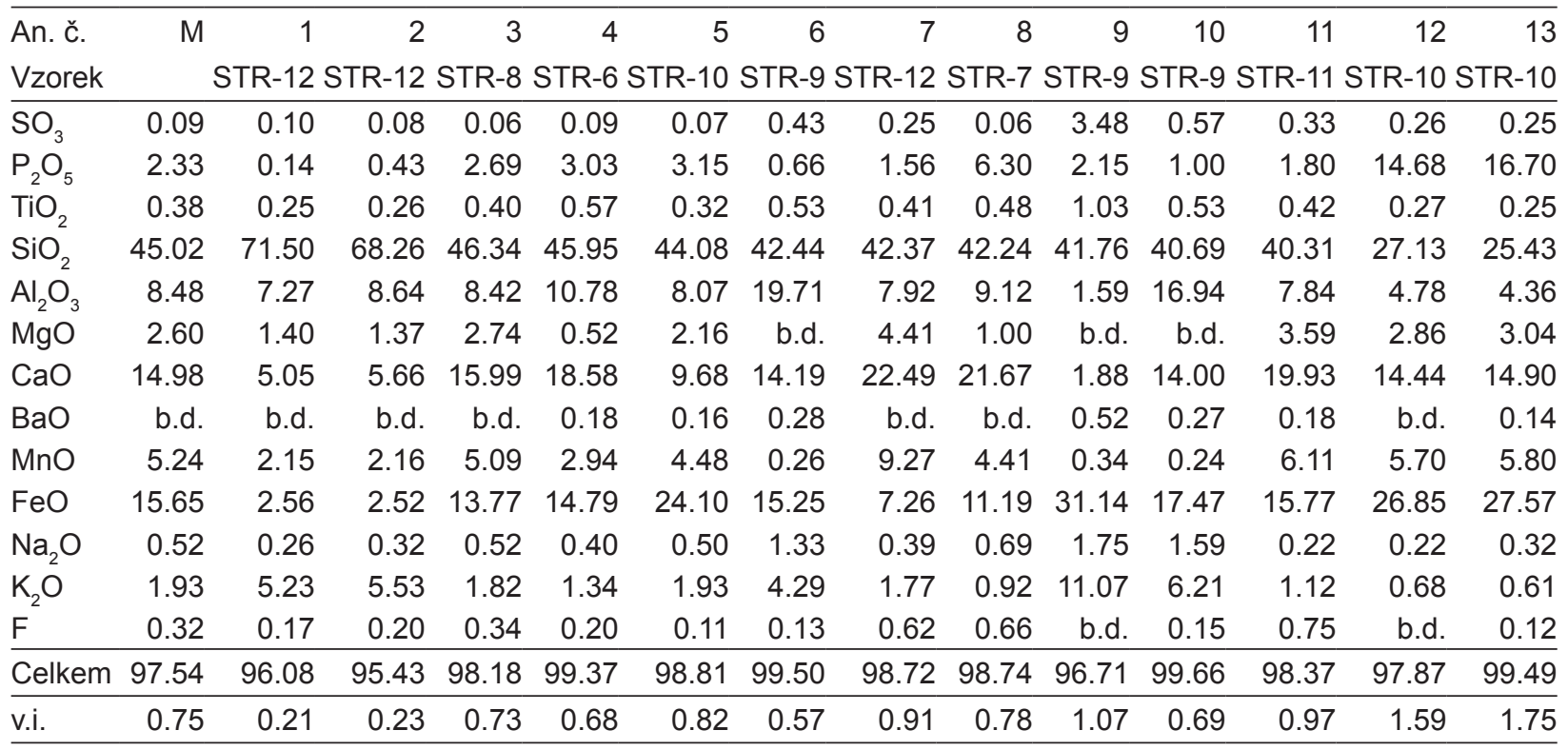



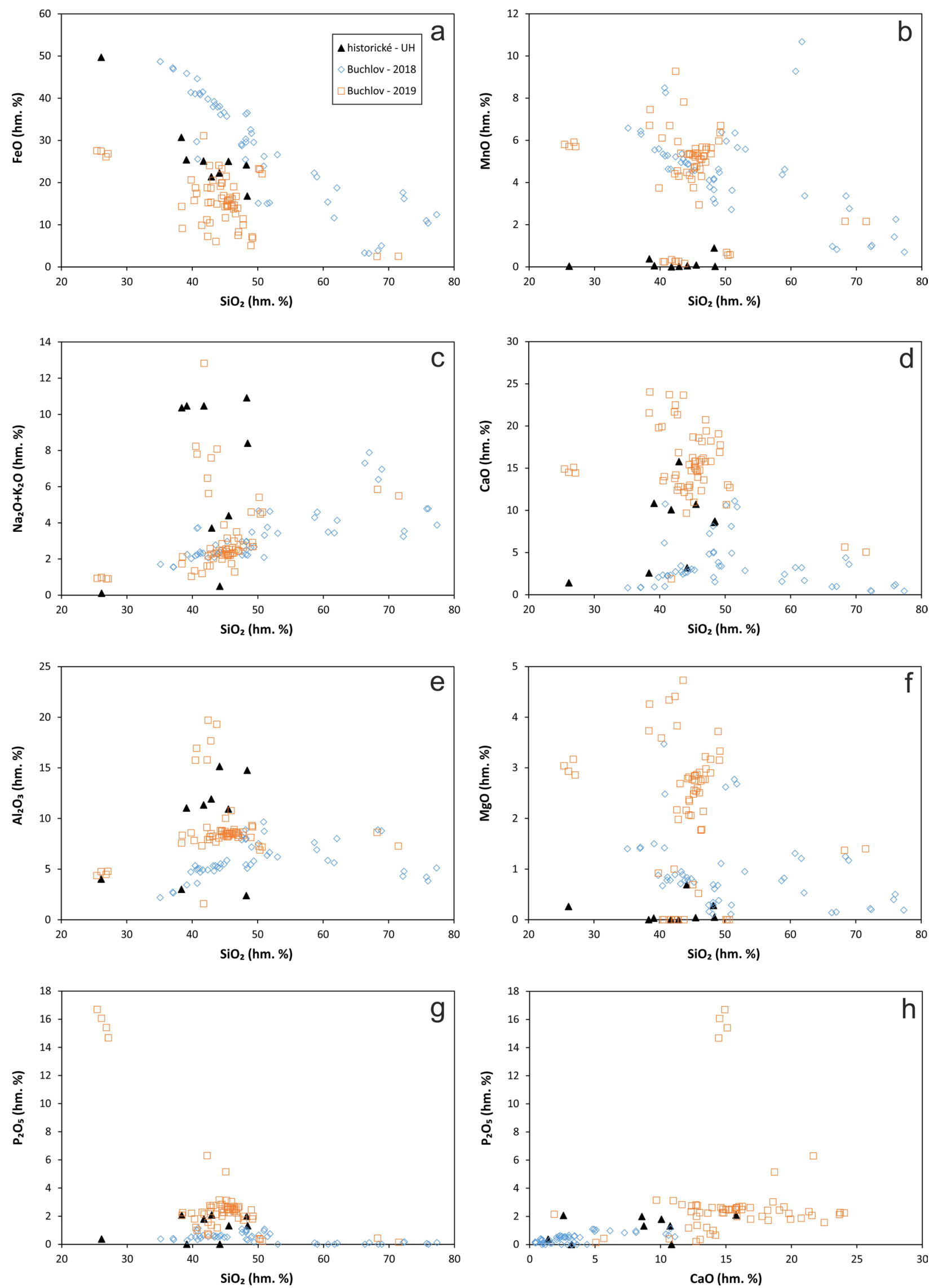

Obr. 4 Variace $v$ chemickém složení skloviny strusek z buchlovské tavby 2019 v porovnání se složením skloviny historických železářských strusek Uherskohradišt'ska (Křivánek 2009, 2015) a skloviny strusek z buchlovské tavby v r. 2018, při níž byla použita limonitová ruda vzniklá zvětráváním pelosideritů (Dolníček et al. 2020). a - diagram SiO - FeO; b - diagram $\mathrm{SiO}_{2}-\mathrm{MnO}$; c - diagram $\mathrm{SiO}_{2}-\mathrm{Na}_{2} \mathrm{O}+\mathrm{K}_{2} \mathrm{O}$; d - diagram $\mathrm{SiO}_{2}-\mathrm{CaO}$; e - diagram $\mathrm{SiO}_{2}-\mathrm{Al}_{2} \mathrm{O}_{3}$; $f$ - diagram $\mathrm{SiO}_{2}-\mathrm{MgO} ; g$ - diagram $\mathrm{SiO}_{2}-\mathrm{P}_{2} \mathrm{O}_{5} ; \mathrm{h}$ - diagram $\mathrm{CaO}-\mathrm{P}_{2} \mathrm{O}_{5}$. 



Obr. 5 Vnitřní stavba a fázové složení studovaných strusek a vyredukovaného železa na BSE snímcích. a - zonální krystaly olivínu v hemikrystalické doméně $4 a v$ asociaci s dendrity wüstitu (bílé) a sklem v mezerách (nejtmavší). Okraje olivínu jsou bohatší fayalitovou a dikalciumsilikátovou složkou a chudši forsteritovou složkou. Vzorek STR-9. b - zonální krystaly olivínu v hemikrystalické doméně 4c v asociaci s kovovým železem (bílé) a sklem v mezerách (nejtmavši). Okraje olivínu jsou bohatší fayalitovou složkou a chudší forsteritovou složkou, zatímco obsah dikalciumsilikátu kolísá nepravidelně. Vzorek STR-9. c - polyfázová doména č. 3, tvořená hlavně dvěmi generacemi lištovitých pyroxenů (Px1, Px2), méně i K-Ca živci (Fs), olivínem (OI) a neprotaveným reliktem křemene (Qtz). Vzorek STR-10. d - srůsty dvou kompozičních typů olivínu (OI1 bohatý dikalciumsilikátovou složkou, Ol2 bohatý fayalitovou složkou), kovového železa ( $F e)$, kalsilitu (Ka), K-bohatého skla (GI) a ojedinělého wüstitu v doméně 4b. Vzorek STR-9. e - objemově převažující izometrická individua nízkofosforového železa obklopená minoritní matricí s vysokým obsahem fosforu v železné kapce ze vzorku STR-11. f - dendritické vyloučeniny nízkofosforového železa uzavřené v objemově dominující fosforem bohatší eutektické směsi železa a schreibersitu v železné kapce ze vzorku STR-8. Všechny snímky Z. Dolníček. 
ojediněle zjištěný mírný přebytek prvků v pozici Si (maximum 1.043 apfu) a sníženou hodnotu Catsum (minimum $1.804 \mathrm{apfu}$ ) Ize vysvětlit náhodnou príměsí skla v analyzovaném „bodě“. S takovou interpretací jsou v souladu i zvýšené obsahy $\mathrm{Al}$ a $\mathrm{v}$ řadě prípadů i malé obsahy $\mathrm{Na}$, $\mathrm{K}$ a Ti, které by $\mathrm{v}$ olivínu neměly být prítomny. Celý získaný soubor analýz vykazuje neobyčejně široké rozsahy obsahů hlavních složek: 1 - 91 mol. \% fayalitu (Fa), 1 - 28 mol. \% forsteritu (Fo), 2 - 45 mol. \% tefroitu (Te) a 1 52 mol. \% dikalciumsilikátu (DCS; tab. 2, 4). V různých (hemi)krystalických doménách je chemické složení olivínu rozdílné. $V$ rámci jedné a téže domény mưže být variabilita chemismu olivínu zcela nepatrná, a to i u velkých krystalů (např. v doménách č. 1 a 8 nepřesahují rozdíly v obsazích jednotlivých složek $3 \mathrm{~mol}$. \%), jindy velmi výrazná (např. u silně zonálních krystalů $z$ domény č. $4 \mathrm{~b}$ až 46 mol. \%). U zonálních krystalů Ize zpravidla konstatovat nárůst obsahu fayalitové komponenty a pokles obsahu forsteritové komponenty během krystalizace, zatímco obsahy tefroitové komponenty se chovají konzervativně (tab. 2). Ke všem uvedeným generalizacím Ize však najít v datovém souboru výjimky (tab. 2). Obsahy dikalciumsilikátové složky od středu k okrajům olivínu ve dvou př́padech rostou, ve dvou naopak klesají (tab. 2). Klasifikačně odpovídá největší část analýz fayalitu, méně často dikalciumsilikátu, v jednom případě i tefroitu (obr. 7a). Ve všech diagramech (obr. 6a-c, 7a) jsou patrné existence diskrétních skupin analýz s podobným složením, odrážejících složení olivínu v konkrétní růstové zóně, krystalické doméně nebo její dílčí partii.

Pyroxen byl zjištěn pouze v doménách č. 1 a 3 , v nichž však tvoři vždy hlavní složku. $V$ doméně č. 3 je přítomen ve dvou generacích. Méně častý starší pyroxen I vytvárí krátce až dlouze sloupečkovité krystaly o velikosti až $0.25 \mathrm{~mm}$ s automorfním až hypautomorfním omezením. V BSE obraze jsou tmavší než pyroxen II a nevykazuji žádnou kompoziční zonálnost. Mladší pyroxen II vytváří hojné, subparalelně či růžicovitě uspořádané dlouze lištovité průřezy o délce až $0.6 \mathrm{~mm}$ a šířce do $50 \mu \mathrm{m}$. V BSE obraze je nezonální a světlejší než pyroxen I. Nikdy nebylo pozorováno, že by pyroxen II narủstal v podobě vnější zóny na krystaly pyroxenu I, vždycky je prítomen jen v samostatných individuích. Této mladší generaci je morfologicky podobný vývin pyroxenu $v$ doméně č. 1 .

Chemické složení pyroxenů bylo ověřeno na základě 25 WDS analýz (tab. 5). Celý datový soubor se vyznačuje poměrně značnou variabilitou, $v$ rámci jednotlivých vzorků či generací Ize však konstatovat podstatně užší rozsahy složení (obr. 6d-f, obr. 7b,c). Ve všech případech jde o pyroxeny s vysokým obsahem vápníku (při přepo-

Tabulka 4 Přiklady chemického složení olivínu ze studovaných strusek. Obsahy oxidů v hm. \%, hodnoty apfu jsou vypočítány na základ 4 atomů kyslíku. Obsahy koncových členů v mol. \%. b.d. - pod mezí stanovitelnosti

\begin{tabular}{|c|c|c|c|c|c|c|c|c|c|c|c|c|c|c|}
\hline n. č. & 1 & 2 & 3 & 4 & 5 & 6 & 7 & 8 & 9 & 10 & 11 & 1 & 13 & \\
\hline & & & & & & & & & & & 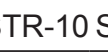 &  & $D_{1}$ & \\
\hline $\mathrm{O}_{5}$ & $d$ & d. & 56 & 69 & b.d. & b.d. & b.d. & 0.18 & .67 & 13 & 1.85 & d. & . & \\
\hline $\mathrm{O}_{2}$ & 9.60 & 30.84 & 28.96 & 1.23 & 31.23 & 0.69 & 32.67 & 32.04 & 32.52 & 33.23 & 0.48 & & & \\
\hline $\mathrm{O}_{2}$ & b.d. & b.d. & 0.06 & b.d. & b.d. & b.d. & b.d. & b.d. & b.d. & b.d. & 0.17 & .05 & b. & \\
\hline${ }_{2} \mathrm{O}_{3}$ & b.d. & b.d. & b.d. & b.d. & b.d. & b.d. & b.d. & b.d. & b.d. & b.d. & 0.27 & d. & . & \\
\hline${ }_{2} \mathrm{O}_{3}$ & 15 & 14 & b.d. & b.d. & b.d. & b.d. & b.d. & b.d. & b.d. & b.d. & . & b.d. & h & \\
\hline gO & 19 & 2.02 & 1.24 & 6.75 & 125 & 6.53 & 10.28 & 2.75 & 4.06 & 6.92 & & & & \\
\hline $\mathrm{aO}$ & & 2 & 3.02 & 1.77 & & & 3 & 19.61 & 28.17 & 28 & & & & \\
\hline nO & 97 & 07 & 2.03 & 9.02 & 1 & 98 & 2.04 & 1.61 & 1.39 & 4 & & & & \\
\hline $\mathrm{O}$ & 71 & .07 & 62.21 & .75 & .93 & .27 & 48.65 & 43.12 & 32.21 & 23.78 & & & & \\
\hline $\mathrm{a}_{2} \mathrm{O}$ & b.d. & b.d. & 0.41 & b.d. & b.d. & b.d. & b.d. & b.d. & 0.17 & 0.25 & 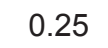 & d. & o. & \\
\hline $\mathrm{O}$ & d. & b.d. & 0.08 & b.d. & b.d. & b.d. & b.d. & b.d. & 0.06 & o.u. & 0.08 & a. & 0.01 & \\
\hline elke & .04 & 0.76 & 3.57 & .21 & 9.38 & 8.701 & 100.37 & 99.31 & 99.25 & 98.73 & & 89 & 77 & \\
\hline+ & d. & d. & 0.016 & 19 & 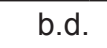 & $d$ & b.d. & 0.005 & 0.017 & 0.028 & & & & \\
\hline $4^{4+}$ & & 14 & 0.9 & 8 & & & 1 & 9 & 0. & 0. & & & & \\
\hline nsu & 90 & 4 & 0.994 & 1.017 & 1.0 & 86 & 1. & 4 & 1.010 & 1.014 & & & . & \\
\hline $4+$ & & d. & 0.0 & b.d. & & & & b.d. & b.d. & b.d. & & & & \\
\hline $3+$ & & d. & b.d. & b.d. & & b.d. & b.d. & b.d. & b.d. & b.d. & & & & \\
\hline $3^{3+}$ & 04 & .004 & b.d. & b.d. & b.d. & b.d. & b.d. & b.d. & b.d. & b.d. & b.d. & b.d. & b. & \\
\hline$g^{2+}$ & & 99 & 0.062 & .322 & 0.0 & .313 & 0.470 & 0.129 & 0.185 & 0.306 & 1 & & & \\
\hline$a^{2+}$ & & & 0 & 1 & 5 & 3 & 0.221 & 2 & 22 & 1. & & & & \\
\hline$n^{2+}$ & & & 0.058 & & & & 0.053 & 0.043 & 0.036 & & & & & \\
\hline $2^{2+}$ & 25 & 89 & & 1.330 & 1.318 & 1.297 & 1.249 & 1.136 & 0.822 & & & & & \\
\hline$a^{+}$ & b.d. & b.d. & 0.027 & b.d. & b.d. & b.d. & b.d. & b.d. & 0.010 & 0.014 & & b.d. & hd & \\
\hline & b.d. & b.d. & 0.003 & b.d. & b.d. & b.d. & b.d. & b.d. & 0.002 & b.d. & & b.d. & & \\
\hline ats & 2.001 & 1.971 & 2.018 & 1.957 & 1.988 & 2.028 & 1.994 & 1.970 & 1.977 & 1.965 & 1.981 & .986 & .975 & \\
\hline$a$ & 1.4 & 90.9 & 88.4 & 68.0 & 66.3 & & 62.6 & 57.7 & 41.9 & 30.2 & 8 & 0.8 & & \\
\hline & & 5.0 & & 16.4 & & & 23.6 & 6.6 & 9.4 & 15.7 & $\angle 2.0$ & & & \\
\hline $\mathrm{CS}$ & 2.0 & 1.1 & & 3.1 & 28.9 & 14.0 & 11.1 & 33.6 & 46.9 & 52.6 & 19.0 & & 41.2 & \\
\hline e & 2.8 & 2.9 & 2.9 & 2.5 & 1.8 & 6.7 & 2.7 & 2.2 & 1.8 & 1.5 & 28.3 & 27.5 & 30.2 & \\
\hline
\end{tabular}


čtu na základ šesti atomů kyslíku se obsahy Ca pohybuji mezi 0.73 a 1.19 apfu). Z vedlejších komponent Ize zmínit zejména $v$ řadě analýz zvýšené obsahy fosforu (až 0.041 apfu), titanu (max. 0.031 apfu) a velmi nízké obsahy alkálií (max. 0.023 apfu Na+K). Při přepočtu analýz na obsahy základních komponent $\left.{ }^{1}\right)$ vycházejí obsahy 37 - 60 mol. \% wollastonitu (Wo), 1 - 13 mol. \% „tschermakitu“ (Tsch), 8 - 22 mol. \% kanoitu (Ka), 4 - 30 mol. \% klinoferosilitu (Fs) a $14-36$ mol. \% klinoenstatitu (En; tab. 2, 5). Starší

1) Přepočet je kalkulován pro obsahy $\mathrm{Ca}+\mathrm{Mg}+\mathrm{Fe}+\mathrm{Mn}+{ }^{v i} \mathrm{Al}=2$. Pro kanoit je uvažován ideální vzorec $\mathrm{Mn}_{2} \mathrm{Si}_{2} \mathrm{O}_{6}$ (srov. též www. webmineral.com); pro ideální složení $\mathrm{MgMnSi}_{2} \mathrm{O}_{6}$ uváděné Morimotem et al. (1988) není u části analýz prítomno dostatečné množství Mg, navíc by pro toto složení vycházela extrémní nestechiometrie empirického vzorce. „Tschermakitová“ komponenta vyjadřuje podíl Al-složky vyjádřené „tschermakitovou“ substitucí ${ }^{i v} \mathrm{Si}^{4+}+{ }^{\mathrm{vi}} \mathrm{Me}^{2+}={ }^{\mathrm{i}} \mathrm{A}{ }^{3+}+{ }^{\mathrm{vi}} \mathrm{Al}^{3+}$
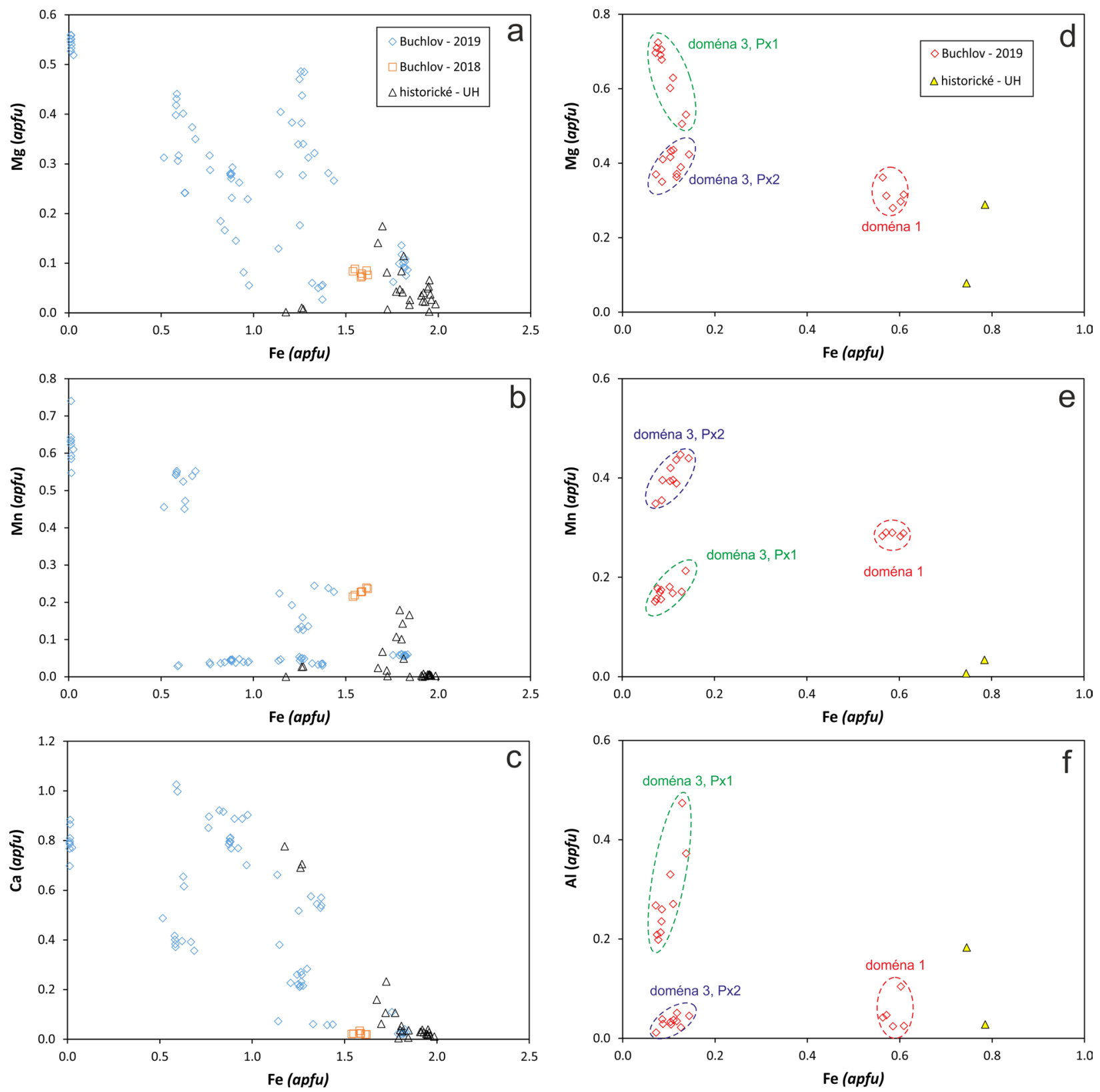

Obr. 6 Variace $v$ chemickém složení olivínu a pyroxenu ze strusek z buchlovské tavby 2019 v porovnání se složením těchto fází z historických železářských strusek Uherskohradišt'ska (Křivánek 2009, 2015) a ze strusek z buchlovské tavby v r. 2018, při níž byla použita limonitová ruda vzniklá zvětráváním pelosideritů (Dolníček et al. 2020). a - diagram Fe - Mg pro olivíny; b - diagram Fe - Mn pro olivíny; c - diagram Fe - Ca pro olivíny; d - diagram Fe - Mg pro pyroxeny; e - diagram $\mathrm{Fe}$ - Mn pro pyroxeny; $f$ - diagram Fe - Al pro pyroxeny. 
-johannsenit (obr. 7b). V diagramu Fe-Mn-Mg padá většina analýz do pole diopsidu, méně často i hedenbergitu a johannsenitu (obr. 7c).

Melilit byl zjištěn jen $v$ jediné hemikrystalické doméně (č. 5), v níž je jako převládající fáze v asociaci s kovovým železem a sklem. Melilit vytváří izometrické, automorfně až hypautomorfně omezené krystaly o velikosti až 130 $\mu \mathrm{m}$. V BSE obraze nevykazují zonálnost. Místy obsahují náhodně rozmístěné inkluze skla a ojediněle i drobné okrouhlé kapky železa. Chemické složení bylo studováno prostřednictvím 11 bodových WDS analýz (tab. 5). Analýzy odpovídají silně substituovanému åkermanitu s 1 - 6 mol. \% gehlenitové molekuly. Křemík je vedle obvyklého hliníku (0.044 až 0.129 apfu při přepočtu na bázi sedmi atomů kyslíku) zčásti zastupován i fosforem (0.004 až 0.107 apfu). Vápník je v malé míre zastupován sodíkem a draslíkem (v součtu 0.063 až 0.126 apfu). Hořčík (0.31 až $0.60 \mathrm{apfu}$ ) je zastupován $\mathrm{Al}(0.19$ až $0.30 \mathrm{apfu}), \mathrm{Mn}(0.10$ až 0.22 apfu) a Fe (0.03 až 0.12 apfu). Pozoruhodné jsou zvýšené obsahy fluoru mezi 0.036 a 0.103 apfu (tab. 5).

Živce jsou přitomny v mezerní hmotě mezi lištami pyroxenů v doménách č. 1 a 3 . Svým tvarem se přizpůsobuji starším pyroxenům. V BSE obraze nevykazují výraznou zonalitu. Jak však ukázaly bodové analýzy (tab. 6), jejich chemické složení místo od místa v obou doménách široce kolísá. Obsah ortoklasové (Or) složky kolísá mezi 2 a 82 mol. \%, anortitové (An) složky 9 - 91 mol. \%, albitové (Ab) složky 5 - 19 mol. \%, celsianové (Cn) složky 0 - 2 mol. \% a slawsonitové (Slw) složky 0 - 2 mol. \% (tab. 2,6). Klasifikačně odpovídají přechodným členům mezi ortoklasem a anortitem (obr. 7d), což jsou složení z přírodních systémů neznámá. Vedle obvyklých komponent byly ve všech analýzách zjištěny i zvýšené obsahy Fe $(0.009$ - $0.097 a p f u), M n(0.006-0.026 a p f u)$ a v řadě prrípadů i $\mathrm{P}$ (max. 0.094 apfu).

Leucit substituuje živce $v$ mezerní hmotě mezi krystaly pyroxenů $v$ doméně č. 3 . Příklady chemického složení jsou uvedeny $v$ tabulce 6 . Chemické složení víceméně
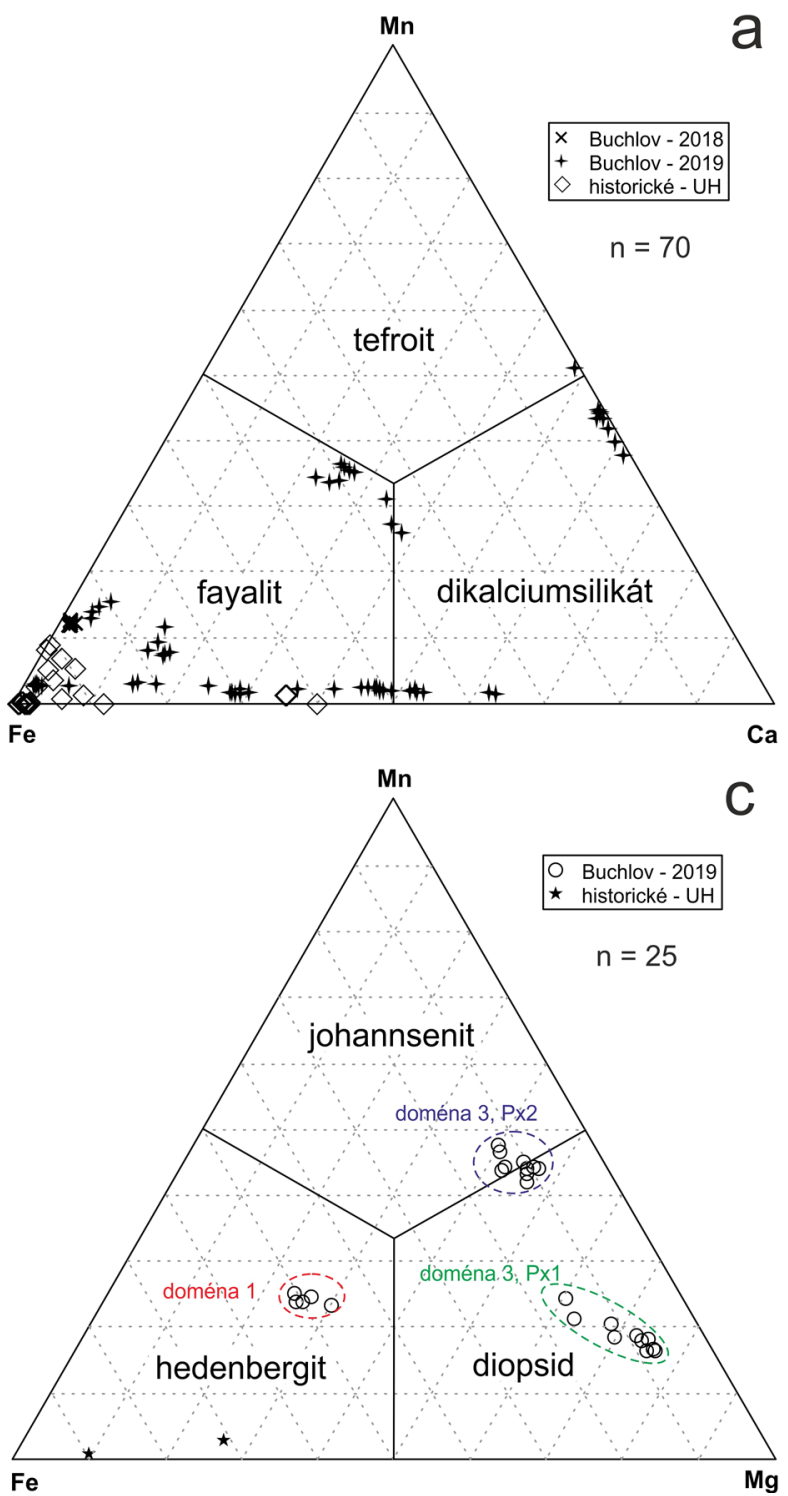


Obr. 7 Klasifikace olivínu, pyroxenu a živců ze studovaných strusek a jejich porovnání se složením těchto fází z historických železářských strusek Uherskohradišt'ska (Křivánek 2009, 2015) a ze strusek z buchlovské tavby v r. 2018, při níž byla použita limonitová ruda vzniklá zvětráváním pelosideritư (Dolníček et al. 2020). a - projekce chemického složení olivínů $v$ diagramu fayalit-tefroit-dikalciumsilikát. $b$ - projekce chemického složení pyroxenů $v$ modifikovaném diagramu podle Morimota et al. (1988). c - projekce chemického složení pyroxenư v diagramu Fe - Mg - Mn pro vápenaté pyroxeny. $d$ - projekce chemického složení živců v diagramu Na - K - Ca (Deer et al. 1963). 
odpovídá teoretickému, jen menší část draslíku je zastupována $\mathrm{Na}(0.048$ - $0.067 \mathrm{apfu}), \mathrm{Ca}(0.003-0.039 \mathrm{apfu})$, $\mathrm{Ba}(0.002$ - $0.010 \mathrm{apfu})$, Sr (max. $0.003 \mathrm{apfu}), \mathrm{Fe}(0.005$ - 0.009 apfu a Mn (0.007 - 0.012 apfu).

Kalsilit se vyskytl $v$ asociaci s olivínem, kovovým železem, wüstitem a draslíkem bohatým sklem v doméně č. 4b. Vytváŕí xenomorfně omezená izometrická až mírně protažená zrna o velikosti až $30 \mu \mathrm{m}$, uzavíraná v olivínu. Př́iklady chemického složení jsou uvedeny $v$ tabulce 6. Chemismus, ověřený sedmi bodovými analýzami, stechiometricky dobře odpovídá ideálnímu vzorci (tab. 6). Menší část hliníku je substituována železem (0.048 až $0.103 \mathrm{apfu}$ ) a malá část draslíku je zastupována $\mathrm{Na}$ (0.010 - $0.016 a p f u)$ a ve čtyřech prípadech i malým množstvím Ca (max. 0.010 apfu).
Nepojmenovaná Ca-Al-Si fáze zastupuje spolu s Ca-Al-P bohatým sklem živce a/nebo leucit v některých partiích mezerní hmoty mezi krystaly pyroxenů v doméně č. 3. Čtyři WDS analýzy ukázaly složení blízké ideálnímu vzorci $\mathrm{Ca}_{2} \mathrm{Al}_{2} \mathrm{Si}_{3} \mathrm{O}_{11}$ (tab. 7), jde tedy chemicky o bezvodý analog prehnitu. Vápník je $v$ dané fázi částečně substituován Na (0.088 - 0.234 apfu), K (0.028 - 0.118 apfu), Ba (0.005 - 0.008 apfu), Fe (0.018 - 0.050 apfu) a Mn (0.030 - 0.062 apfu). Křemík je poměrně významně zastupován fosforem (0.07 - 0.50 apfu).

Apatit byl zjištěn jako jediná krystalická fáze v hemikrystalické doméně č. 2. Často duté, automorfně omezené jehlicovité krystaly apatitu dosahují délky až $50 \mu \mathrm{m}$ a jsou uzavírány ve fosforem velmi bohaté (15.4 - $16.7 \mathrm{hm}$. $\% \mathrm{P}_{2} \mathrm{O}_{5}$ ) smouze skloviny (obr. $3 d$ ). Pět bodových analýz

Tabulka 5 Příklady chemického složení pyroxenů $(P x)$ a melilitu (Mel) ze studovaných strusek. Obsahy oxidů v hm. $\%$, hodnoty apfu jsou vypočitány na základ 6 (pyroxeny), resp. 7 (melilit) atomů kyslíku. Obsahy koncových členů v mol. \%. Px I, Px II - dvě generace pyroxenů z domény č. 3, Px - pyroxeny z domény č. 1. b.d. - pod mezí stanovitelnosti, n.a. - neanalyzováno

\begin{tabular}{|c|c|c|c|c|c|c|c|c|c|c|c|c|c|c|}
\hline n. č. & 1 & 2 & 3 & 4 & 5 & 6 & 7 & 8 & 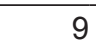 & 10 & 11 & 12 & 13 & 14 \\
\hline liner & PxI & PxI & PxI & $x$ II & x II & PX II & $P x$ & $P x$ & $P x$ & Mel & Mel & Mel & Mel & \\
\hline \multicolumn{15}{|c|}{ zorek STR-10STR-10STR-10STR-10STR-10STR-10STR-10STR-10STR-10STR-11STR-11STR-11STR-11STR-11 } \\
\hline $\mathrm{O}_{5}$ & 34 & .44 & 1.06 & b.d. & b.d. & 0.25 & b.d. & 0.44 & 1.02 & b.d. & 2.69 & 0.22 & .14 & 0.13 \\
\hline $\mathrm{O}_{2}$ & 5.48 & 9.26 & 4.77 & 50.95 & 51.11 & 49.99 & 9.37 & 48.97 & 47.29 & 41.45 & 37.54 & 0.89 & 10.60 & 2.05 \\
\hline $\mathrm{O}_{2}$ & 08 & 0.65 & 1.01 & 0.09 & 0.15 & 0.19 & 0.09 & 0.10 & 39 & b.d. & 0.10 & 0.05 & b.d. & b.c \\
\hline${ }_{2} \mathrm{O}_{3}$ & .59 & 4.78 & 8.16 & 0.25 & 0.63 & 0.98 & 0.51 & 0.89 & 2.20 & 4.58 & 7.07 & 6.93 & 7.42 & 4.7 \\
\hline${ }_{2} \mathrm{O}_{3}$ & 05 & 0.0 & d. & d. & b.d. & b.d. & b.d. & d. & d. & n.a. & n.a. & n.a. & n.a. & or \\
\hline nO & 5.31 & & 6.49 & 0 & ... & & & & & 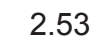 & 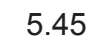 & & & " \\
\hline 0 & & & Or & & 0 & & . & & & 1.47 & & & & 0 \\
\hline $\mathrm{gO}$ & .94 & 21 & 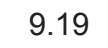 & 634 & 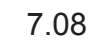 & & & & & 66 & 9 & & 15 & 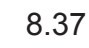 \\
\hline $\mathrm{aO}$ & .08 & .96 & 22.68 & .50 & 25.80 & 26.00 & 18.98 & 8 & 95 & 40 & 6 & 1 & 55 & 0 \\
\hline $\mathrm{a}_{2} \mathrm{O}$ & b.d. & d. & 0.15 & b.d. & b.d. & b.d. & b.d. & b.d. & b.d. & 0.69 & 0.38 & 0.44 & 0.29 & 0.5 \\
\hline O & 0.05 & 0.04 & 0.05 & b.d. & b.d. & b.d. & b.d. & 0.04 & 0.45 & 0.79 & 1.21 & 0.74 & 0.73 & 0.7 \\
\hline & & & & & & & & & & & & & & \\
\hline
\end{tabular}

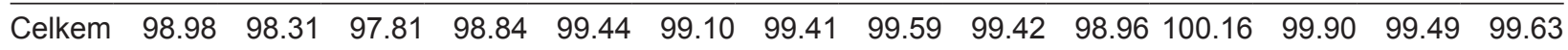

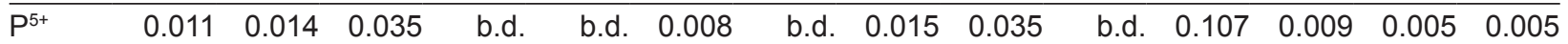

$\begin{array}{lllllllllllllll}\mathrm{Si}^{4+} & 1.726 & 1.865 & 1.733 & 1.995 & 1.989 & 1.965 & 1.992 & 1.959 & 1.904 & 1.940 & 1.768 & 1.884 & 1.881 & 1.951\end{array}$

\begin{tabular}{lllllllllllllll} 
iv $^{\text {Al }}{ }^{3+}$ & 0.263 & 0.121 & 0.232 & 0.005 & 0.011 & 0.027 & 0.008 & 0.026 & 0.061 & 0.060 & 0.125 & 0.107 & 0.114 & 0.044 \\
\hline
\end{tabular}

\begin{tabular}{lllllllllllllll}
\hline Subtot. & 2.000 & 2.000 & 2.000 & 2.000 & 2.000 & 2.000 & 2.000 & 2.000 & 2.000 & 2.000 & 2.000 & 2.000 & 2.000 & 2.000
\end{tabular}

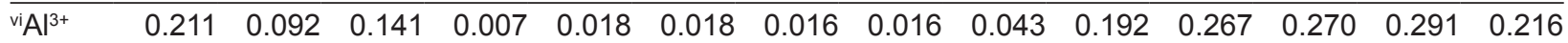

$\begin{array}{llllllllllllll}\mathrm{Ti}^{4+} & 0.031 & 0.019 & 0.029 & 0.003 & 0.004 & 0.006 & 0.003 & 0.003 & 0.012 & \text { b.d. } 0.004 & 0.002 & \text { b.d. } & \text { b.d. }\end{array}$

$\mathrm{V}^{3+} \quad 0.0020 .002$ b.d. b.d. b.d. b.d. b.d. b.d. b.d. n.a. n.a. n.a. n.a. n.a.

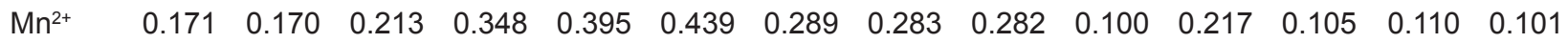

$\begin{array}{lllllllllllllll}\mathrm{Fe}^{2+} & 0.129 & 0.082 & 0.138 & 0.072 & 0.087 & 0.144 & 0.585 & 0.563 & 0.602 & 0.058 & 0.102 & 0.042 & 0.045 & 0.081\end{array}$

\begin{tabular}{llllllllllllllll}
$\mathrm{Mg}^{2+}$ & 0.506 & 0.691 & 0.530 & 0.370 & 0.411 & 0.424 & 0.280 & 0.362 & 0.297 & 0.604 & 0.308 & 0.556 & 0.514 & 0.579 \\
\hline
\end{tabular}

\begin{tabular}{llllllllllllllll} 
Subtot. & 1.049 & 1.055 & 1.051 & 0.800 & 0.916 & 1.031 & 1.173 & 1.227 & 1.237 & 0.954 & 0.898 & 0.974 & 0.961 & 0.977 \\
\hline
\end{tabular}

\begin{tabular}{lllllllllllllll}
\hline $\mathrm{Ca}^{2+}$ & 0.939 & 0.931 & 0.941 & 1.196 & 1.076 & 0.964 & 0.820 & 0.766 & 0.731 & 1.925 & 1.920 & 1.897 & 1.913 & 1.888
\end{tabular}

$\begin{array}{lllllllllllllll}\mathrm{Na}^{+} & \text {b.d. } & \text { b.d. } & 0.011 & \text { b.d. } & \text { b.d. } & \text { b.d. } & \text { b.d. } & \text { b.d. } & \text { b.d. } & 0.063 & 0.035 & 0.039 & 0.026 & 0.051\end{array}$

\begin{tabular}{lllllllllllllll}
$\mathrm{K}^{+}$ & 0.002 & 0.002 & 0.002 & b.d. & b.d. & b.d. & b.d. & 0.002 & 0.023 & 0.047 & 0.073 & 0.044 & 0.043 & 0.043 \\
\hline
\end{tabular}

\begin{tabular}{lllllllllllllll}
\hline Subtot. & 0.941 & 0.933 & 0.955 & 1.196 & 1.076 & 0.964 & 0.820 & 0.768 & 0.754 & 2.035 & 2.028 & 1.980 & 1.983 & 1.982
\end{tabular}

$\begin{array}{lllllllllllllll}\text { Catsum } & 3.990 & 3.989 & 4.006 & 3.996 & 3.992 & 3.995 & 3.993 & 3.996 & 3.991 & 4.989 & 4.925 & 4.954 & 4.943 & 4.959\end{array}$

\begin{tabular}{|c|c|c|c|c|c|c|c|c|c|c|c|c|c|}
\hline $\mathrm{F}$ & n.a. & n.a. & n.a. & n.a. & n.a. & n.a. & n.a. & n.a. & n.a. & 0.058 & 0.103 & $0.050 \quad 0.051$ & 0.056 \\
\hline Wo & 47 & 47 & 47 & 60 & 54 & 48 & 41 & 38 & 37 & & & & \\
\hline Tsch & 13 & 6 & 9 & 1 & 2 & 1 & 1 & 1 & 4 & & & & \\
\hline $\mathrm{Ka}$ & 9 & 8 & 11 & 17 & 20 & 22 & 14 & 14 & 14 & & & & \\
\hline Fs & 6 & 4 & 7 & 4 & 4 & 7 & 29 & 28 & 30 & & & & \\
\hline En & 25 & 35 & 27 & 19 & 21 & 21 & 14 & 18 & 15 & & & & \\
\hline
\end{tabular}


apatitu (tab. 8) ukázalo, že fosfor je zastupován křemíkem (0.094 - $0.327 a p f u)$ a v menší míře i sírou (0.006 - 0.010 $a p f u)$. Vápník je zčásti nahrazován Fe (0.19 - 0.36 apfu), Mn (0.09- $0.13 a p f u)$ a Al (0.01 - $0.08 a p f u)$. Vzhledem $\mathrm{k}$ velmi malé šířce jehlic (max. $\sim 5 \mu \mathrm{m}$ ) nelze vyloučit, že zvýšené obsahy Al a Si mohou minimálně zčásti pocházet i z okolního skla, zachyceného elektronovým paprskem $v$ analyzovaném bodě. Obsah fluoru se pohybuje mezi 0.63 a 0.84 apfu, ve všech prípadech jde tedy klasifikačně o fluorapatit.

Wüstit je akcesorickou komponentou domén č. 4a, 4 b a 7 (tab. 2). Pouze ve vzorku $4 a$ vytvárí charakteristické dendrity rostlé podle stěn krychle, o velikosti až 70 $\mu \mathrm{m}$, uzavírané ve fayalitu a skle (obr. 5a). V druhých dvou doménách vytváří drobné (velikost do $5 \mu \mathrm{m}$ ) okrouhlé či nepravidelné inkluze uzavírané ve fayalitu či na hranici kovového železa a kalsilitu (obr. 5d). V BSE obraze je nezonální. Šest bodových WDS analýz ukázalo příměsi Si, $\mathrm{Al}, \mathrm{Cr}, \mathrm{Ti}$ a Ca nepřesahující 0.007 apfu a menší príměsi Mg a Mn do 0.003 apfu (tab. 9).

Kovové železo je většinou prítomno v podobě dokonale kulatých nebo alespoň oválných kapek (o průměru max. $5 \mathrm{~mm}$, většinou však méně než $1 \mathrm{~mm}$ ), v malém množství náhodně uzavíraných ve strusce (obr. 3b,c). Jak v odrazovém mikroskopu, tak na BSE snímcích je patrná kompozičně nehomogenní vnitřní stavba kovu. Jak ukázaly mikrosondové analýzy (tab. 10), hlavním prvkem, který je príčinou pozorované texturní nehomogenity, je fosfor. Pro všechny kapky kovu je charakteristická přítomnost okrouhlých až polygonálních individuí nízkofosforového železa (s obsahem P mezi 0.4 a 2.0 hm. \%), které jsou někdy krystalograficky zákonitě uspořádané (obr. 5f) a uzavřené v homogenní či jemně zrnité matrici se zvýšeným obsahem fosforu (6.2 - 10.9 hm. \% P). Kvantitativní zastoupení obou složek je proměnlivé, v různých kapkách se podíl fosforem bohaté matrice pohybuje mezi cca 20 a 70 obj. \% (obr. 5e,f). Značně proměnlivý je v důsledku toho i celkový obsah fosforu v jednotlivých kapkách, který kolísá mezi 1.5 a 6.6 hm. \%. Ve fosforem nejbohatší kapce (obr. 5f) byla ve zřetelně zrnité, fosforem bohaté matrici vzácně zjištěna i v BSE obraze poněkud tmavší, velmi drobná (do $10 \mu \mathrm{m}$ velké) zrna nepravidelného tvaru ještě bohatší fosforem (maximum 14.5 hm. \% P; tab. 10), která složením odpovídají téměř čistému schreibersitu $\left(\mathrm{Fe}_{3} \mathrm{P}\right.$, ideálně $15.6 \mathrm{hm}$. \% P). Vedle Fe a P byly mikrosondovými analýzami (tab. 9) zaznamenány ve většině analýz ještě př́měsi Co (max. $0.11 \mathrm{hm}$. \%) a zcela ojediněle i Ni (max. $0.07 \mathrm{hm}$. \%). Asi v polovině analýz byly zaznamenány i měřitelné obsahy síry [obvykle mezi 0.03 a $0.21 \mathrm{hm}$. \%, v pěti analýzách (pocházejících z jedné kapky) i vyšší, mezi 0.47 a 0.55 hm. \%]. S výjimkou pěti analýz Ize konstatovat uspokojivé analytické sumy mezi 99.4 a $100.5 \mathrm{hm}$. \%,

Tabulka 6 Přiklady chemického složení živců (Fs), leucitu (Le) a kalsilitu (Ka) ze studovaných strusek. Obsahy oxidů $v \mathrm{hm}$. \%, hodnoty apfu jsou vypočítány na základ 8 (živce), 6 (leucit), resp. 4 (kalsilit) atomů kyslíku. Obsahy koncových členů v mol. \%. b.d. - pod mezí stanovitelnosti

\begin{tabular}{|c|c|c|c|c|c|c|c|c|c|c|c|c|c|c|}
\hline An. č. & 1 & 2 & 3 & 4 & 5 & 6 & 7 & 8 & 9 & 10 & 11 & 12 & 13 & \\
\hline Fáze & Fs & Fs & Fs & Fs & Fs & Fs & Fs & Fs & Le & Le & Le & $\mathrm{Ka}$ & $\mathrm{Ka}$ & 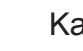 \\
\hline \multicolumn{15}{|l|}{ Vzorek } \\
\hline $\mathrm{P}_{2} \mathrm{O}_{5}$ & .17 & 0.12 & 0.07 & b.d. & 0.28 & 0.11 & 2.32 & 0.08 & b.d. & b.d. & b.d. & b.d. & b.d. & N. \\
\hline $\mathrm{SiO}_{2}$ & 45.66 & 48.01 & 53.84 & 57.13 & 56.42 & 57.35 & 53.38 & 60.67 & 4.19 & 4.99 & 54.78 & 37.75 & 38.69 & 7.9 \\
\hline $\mathrm{Al}_{2} \mathrm{O}_{3}$ & 33.42 & 30.60 & 26.53 & 24.38 & 23.84 & 23.12 & 24.11 & 19.11 & 23.88 & 23.46 & 22.87 & 30.18 & 29.63 & 7 \\
\hline $\mathrm{aO}$ & 18.11 & 14.84 & 11.81 & 8.11 & 8.29 & 6.93 & 3.38 & 1.71 & 0.09 & 0.07 & 0.09 & 0.05 & b.d. & \\
\hline rO & b.d. & 0.63 & b.d. & 0.15 & b.d. & 0.14 & b.d. & 0.10 & 0.10 & b.d. & 0.10 & b.d. & 0.11 & \\
\hline $\mathrm{aO}$ & 0.14 & 0.62 & 0.22 & 0.29 & 0.45 & 0.36 & 0.66 & 0.21 & 0.47 & 0.15 & 0.26 & 0.10 & b.d. & \\
\hline nO & 0.39 & 0.34 & 0.36 & 0.15 & 0.43 & 0.29 & 0.44 & 0.14 & 0.25 & 0.25 & 0.25 & 0.15 & b.d. & \\
\hline $\mathrm{eO}$ & 0.56 & 0.27 & 1.39 & 1.03 & 2.10 & & 0.23 & & 0.20 & & & 2.16 & 2.41 & 2.2 \\
\hline $\mathrm{a}_{2} \mathrm{O}$ & 0.77 & 1.49 & 1.65 & 2.09 & 1.45 & 1.18 & 0.56 & 1.05 & 0.76 & 0.91 & 0.88 & 0.33 & 0.20 & \\
\hline $\mathrm{K}_{2} \mathrm{O}$ & 32 & 1.95 & 4.40 & 6.53 & 7.43 & 874 & 12.50 & 13.80 & 64 & 19.35 & 19.77 & 29.10 & 28.68 & $28 \mathrm{c}$ \\
\hline Celkem & .54 & 98.87 & 100.27 & 99.86 & 100.69 & 8 & 8 & 97 & 99.58 & 99.36 & 99.17 & 99.83 & 99.721 & 10 \\
\hline $25+$ & 0 & 0. & & b.d. & & & & & & & & b.d. & b.d. & \\
\hline $\mathrm{Si}^{4+}$ & 2.124 & 2.258 & 2.485 & 2.635 & 2.610 & 2.671 & 2.553 & 2.892 & 1.976 & 1.997 & 2.003 & 1.008 & 1.029 & 1.00 \\
\hline $\mathrm{Al}^{3+}$ & 1.832 & 1.696 & 1.443 & 1.326 & 1.300 & 1.269 & 1.359 & 1.074 & 1.026 & 1.004 & 0.986 & 0.950 & 0.929 & 0.96 \\
\hline $\mathrm{Ca}^{2+}$ & 03 & 0.748 & 0.584 & 0.401 & 0.411 & 0.346 & 0.173 & 0.087 & 0.004 & 0.003 & 0.004 & 0.001 & b.d. & \\
\hline $\mathrm{Sr}^{2+}$ & b.d. & 0.017 & b.d. & 0.004 & b.d. & 0.004 & b.d. & 0.003 & 0.002 & b.d. & 0.002 & b.d. & 0.002 & \\
\hline $\mathrm{Ba}^{2+}$ & .003 & 0.011 & 0.004 & 0.005 & .008 & 0.007 & 0.012 & 0.004 & 0.007 & 0.002 & 0.004 & 0.001 & b.d. & \\
\hline $\mathrm{ln}^{2+}$ & 15 & 0.014 & 0.014 & 0.006 & 0.017 & 0.011 & 0.018 & 0.006 & 0.008 & 0.008 & 0.008 & 0.003 & b.d. & \\
\hline $\mathrm{Fe}^{2+}$ & 22 & 0.011 & 0.054 & 0.040 & 81 & 0.064 & 0.009 & 0.028 & 0.006 & 05 & 0.005 & 0.048 & 0.054 & 0.05 \\
\hline $\mathrm{Na}^{+}$ & 0.069 & 0.136 & 0.148 & 0.187 & 0.130 & 0.107 & 0.052 & 0.097 & 0.054 & 0.064 & 0.062 & 0.017 & 0.010 & 0.01 \\
\hline $\mathrm{K}^{+}$ & 0.019 & 0.117 & 0.259 & 0.384 & 0.439 & 0.519 & 0.763 & 0.839 & 0.913 & 0.897 & 0.922 & 0.992 & 0.974 & 0.97 \\
\hline Catsum & 4.994 & 5.013 & 4.993 & 4.988 & 5.007 & 5.001 & 5.034 & 5.034 & 3.995 & 3.981 & 3.996 & 3.021 & 2.998 & 3.0 \\
\hline$\overline{\text { Or }}$ & & & 26.0 & 39.2 & 44.4 & 52.9 & 76.3 & 81.5 & & & & & & \\
\hline An & 90.8 & 72.7 & 58.7 & 40.8 & 41.6 & 35.2 & 17.3 & 8.5 & & & & & & \\
\hline$A b$ & 7.0 & 13.2 & 14.8 & 19.0 & 13.2 & 10.9 & & 9.4 & & & & & & \\
\hline $\mathrm{Cn}$ & 0.3 & 1.1 & 0.4 & 0.5 & 0.8 & 0.7 & 1.2 & 0.4 & & & & & & \\
\hline Slw & 0 & 1.7 & 0 & 0.4 & 0 & 0.4 & 0 & 0.3 & & & & & & \\
\hline
\end{tabular}


Tabulka 7 Chemické složení nepojmenované Ca-Al-Si fáze ze vzorku STR-10. Obsahy oxidů v hm. \%, hodnoty apfu jsou vypočitány na základ 11 atomů kyslíku.

\begin{tabular}{lrrrr}
\hline $\mathrm{An}$. č. & 1 & 2 & 3 & 4 \\
\hline $\mathrm{P}_{2} \mathrm{O}_{5}$ & 9.05 & 6.06 & 5.94 & 1.25 \\
$\mathrm{SiO}_{2}$ & 38.00 & 39.99 & 40.20 & 43.55 \\
$\mathrm{Al}_{2} \mathrm{O}_{3}$ & 25.60 & 25.83 & 25.62 & 25.25 \\
$\mathrm{CaO}$ & 23.26 & 21.85 & 22.39 & 25.30 \\
$\mathrm{BaO}$ & 0.19 & 0.31 & 0.26 & 0.23 \\
$\mathrm{MnO}$ & 0.74 & 0.86 & 1.11 & 0.53 \\
$\mathrm{FeO}$ & 0.74 & 0.79 & 0.91 & 0.33 \\
$\mathrm{Na}_{2} \mathrm{O}$ & 1.60 & 1.82 & 1.59 & 0.68 \\
$\mathrm{~K}_{2} \mathrm{O}$ & 1.42 & 1.29 & 1.20 & 0.32 \\
\hline $\mathrm{Celkem}^{5+}$ & 100.60 & 98.80 & 99.22 & 97.44 \\
\hline $\mathrm{P}^{5+}$ & 0.498 & 0.340 & 0.333 & 0.071 \\
$\mathrm{Si}^{4+}$ & 2.472 & 2.650 & 2.658 & 2.936 \\
$\mathrm{Al}^{3+}$ & 1.963 & 2.018 & 1.997 & 2.006 \\
$\mathrm{Ca}^{2+}$ & 1.621 & 1.552 & 1.586 & 1.827 \\
$\mathrm{Ba}^{2+}$ & 0.005 & 0.008 & 0.007 & 0.006 \\
$\mathrm{Mn}^{2+}$ & 0.041 & 0.048 & 0.062 & 0.030 \\
$\mathrm{Fe}^{2+}$ & 0.040 & 0.044 & 0.050 & 0.019 \\
$\mathrm{Na}^{+}$ & 0.202 & 0.234 & 0.204 & 0.089 \\
$\mathrm{~K}^{+}$ & 0.118 & 0.109 & 0.101 & 0.028 \\
\hline $\mathrm{Catsum}^{+}$ & 6.959 & 7.002 & 6.998 & 7.012 \\
\hline & & & &
\end{tabular}

Tabulka 8 Přiklady chemického složení apatitu (Ap) a fosfátu $\mathrm{Fe}(\mathrm{Fe}-\mathrm{P})$ ze studovaných strusek. Obsahy oxidů v hm. \%, hodnoty apfu jsou vypočítány na základ 12.5 (apatit), respektive 8 (fosfát Fe) atomů kyslíku. b.d. - pod mezí stanovitelnosti, n.a. - neanalyzováno

\begin{tabular}{lrrrrrr}
\hline An. č. & 1 & 2 & 3 & 4 & 5 & 6
\end{tabular}

Fáze Ap Ap Ap Ap Fe-P Fe-P

Vzorek STR-8 STR-8 STR-8 STR-8 STR-10 STR-10

$\begin{array}{lllllll}\mathrm{SO}_{3} & 0.10 & 0.09 & 0.09 & 0.15 & \text { n.a. } & \text { n.a. }\end{array}$

$\begin{array}{lllllll}\mathrm{P}_{2} \mathrm{O}_{5} & 39.24 & 39.33 & 40.95 & 37.56 & 37.86 & 37.41\end{array}$

$\begin{array}{lllllll}\mathrm{SiO}_{2} & 2.44 & 2.60 & 1.12 & 3.52 & 0.65 & 1.00\end{array}$

$\begin{array}{lllllll}\mathrm{Al}_{2} \mathrm{O}_{3} & 0.45 & 0.43 & 0.14 & 0.49 & \text { b.d. } & \text { b.d. }\end{array}$

$\begin{array}{lllllll}\mathrm{CaO} & 51.08 & 50.65 & 51.82 & 48.72 & 0.38 & 0.43\end{array}$

$\begin{array}{lllllll}\mathrm{MnO} & 1.43 & 1.42 & 1.26 & 1.69 & \text { b.d. } & 0.15\end{array}$

$\begin{array}{lllllll}\mathrm{FeO} & 3.00 & 3.11 & 2.75 & 3.80 & 60.79 & 60.80\end{array}$

$\begin{array}{lllllll}\mathrm{K}_{2} \mathrm{O} & 0.12 & 0.11 & 0.04 & 0.17 & \text { n.a. n.a. }\end{array}$

$\begin{array}{llllllr}\mathrm{F} & 2.58 & 2.50 & 2.80 & 2.50 & \text { n.a. } & \text { n.a. }\end{array}$

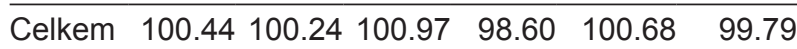

\begin{tabular}{llllllr}
\hline $\mathrm{S}^{6+}$ & 0.006 & 0.006 & 0.006 & 0.010 & n.a. & n.a.
\end{tabular}

$\begin{array}{lllllll}\mathrm{P}^{5+} & 2.821 & 2.826 & 2.924 & 2.753 & 1.933 & 1.911\end{array}$

\begin{tabular}{lllllll}
$\mathrm{Si}^{4+}$ & 0.207 & 0.221 & 0.094 & 0.305 & 0.039 & 0.060 \\
\hline Ansum & 3.034 & 3.052 & 3.024 & 3.068 & 1.972 & 1.971
\end{tabular}

\begin{tabular}{lllllll}
\hline Ansum & 3.034 & 3.052 & 3.024 & 3.068 & 1.972 & 1.971 \\
\hline
\end{tabular}

\begin{tabular}{lllllll}
\hline $\mathrm{Al}^{3+}$ & 0.045 & 0.043 & 0.014 & 0.050 & b.d. & b.d.
\end{tabular}

$\begin{array}{lllllll}\mathrm{Ca}^{2+} & 4.647 & 4.605 & 4.683 & 4.520 & 0.025 & 0.028\end{array}$

$\begin{array}{lllllll}\mathrm{Mn}^{2+} & 0.103 & 0.102 & 0.090 & 0.124 & \text { b.d. } & 0.008\end{array}$

$\begin{array}{lllllll}\mathrm{Fe}^{2+} & 0.213 & 0.221 & 0.194 & 0.275 & 3.065 & 3.067\end{array}$

$\begin{array}{lllllll}\mathrm{K}^{+} & 0.013 & 0.012 & 0.004 & 0.019 & \text { n.a. } & \text { n.a. }\end{array}$

\begin{tabular}{lllllll}
\hline Catsum & 5.021 & 4.983 & 4.985 & 4.987 & 3.090 & 3.103
\end{tabular}

$\mathrm{F}^{-}$

$\begin{array}{llllll}0.693 & 0.671 & 0.747 & 0.685 & \text { n.a. } & \text { n.a. }\end{array}$

které vylučují možnost přítomnosti výrazněji zvýšených koncentrací uhlíku v kovu.

Odlišný charakter má výskyt kovového železa $v$ doméně $4 \mathrm{~b}$ ze vzorku nístějové strusky. Zde je železo prítomno $v$ podobě drobných hojných izolovaných inkluzí nepravidelného tvaru o velikosti maximálně $20 \mu \mathrm{m}$, uzavíraných $v$ silikátové matrici (obr. $5 \mathrm{~d}$ ). $V$ tomto prípadě kov neobsahuje žádný fosfor ani síru, obsahy Co jsou však zcela srovnatelné (max. $0.1 \mathrm{hm}$. \%) s výše popsanými P-bohatými kovovými kapkami. Zvýšené jsou naopak v kovu obsahy $\mathrm{Ca}$, jehož obsah se pohybuje mezi 0.10 a $0.61 \mathrm{hm}$. \%. Zvýšené obsahy Ca nejsou doprovázeny zvýšenými koncentracemi žádných dalších měřených „litofilních" prvků ( $\mathrm{Si}, \mathrm{Al}, \mathrm{Mg}, \mathrm{Mn})$. Analytické sumy se pohybují mezi 99.7 a 100.3 hm. \% (tab. 10).

Okolo jedné větší železné kapky ve vzorku STR-10 byl zjištěn neprůběžný lem mocný maximálně $60 \mu \mathrm{m}$, tvořený hlavně izometrickými a lištovitě protaženými individui oxidu železa, jejichž stechiometrie odpovídá wüstitu. Mezery mezi zrny oxidu Fe jsou vyplněny fosfátem železa, jehož chemické složení přibližně odpovídá vzorci $\mathrm{Fe}_{3}\left(\mathrm{PO}_{4}\right)_{2}$ (viz tab. 8).

\section{Diskuse}

Fázové složení strusek spolu s chemickým složením jednotlivých fází strusek velmi dobře reflektuje chemické složení použité železné rudy. Zvýšené obsahy $\mathrm{Ca}, \mathrm{Mg}$ a Mn jsou pro pelosiderity z lokality Moravany velmi charakteristické - jejich hlavní složkou je siderit až Mn-bohatý siderit se zvýšenými obsahy $\mathrm{Ca}$ a $\mathrm{Mg}$ a vedle toho konkrece běžně obsahují i mladší kalcitové žilky (Dolníček et al. 2019). Zvýšené obsahy Al ve strusce odrážejí vyšší príměs detritické příměsi a/nebo hostitelské horniny, již jsou jílovce. Vedle karbonátů a detritické príměsi byl v akcesorickém množství v pelosideritech identifikován i pyrit, v němž byly zjištěny příměsi $\mathrm{Ni}, \mathrm{Co}, \mathrm{Pb}, \mathrm{Mn}$ a $\mathrm{Hg}$ (Dolníček et al. 2019). Siderofilní prvky (Co a vzácněji i

Tabulka 9 Př́klady chemického složení wüstitu ze vzorku STR-9. Obsahy oxidů v hm. \%, hodnoty apfu jsou vypočítány na základ 1 atomu kyslíku. b.d. - pod mezi stanovitelnosti

\begin{tabular}{lrrrrrr}
\hline An. č. & 1 & 2 & 3 & 4 & 5 & 6 \\
\hline $\mathrm{SiO}_{2}$ & 0.40 & 0.47 & 0.29 & 0.30 & 0.26 & 0.17 \\
$\mathrm{TiO}_{2}$ & 0.12 & 0.08 & 0.11 & 0.15 & 0.20 & 0.62 \\
$\mathrm{Al}_{2} \mathrm{O}_{3}$ & 0.34 & 0.24 & 0.23 & 0.23 & 0.45 & 0.14 \\
$\mathrm{Cr}_{2} \mathrm{O}_{3}$ & b.d. & b.d. & 0.07 & 0.05 & 0.14 & 0.47 \\
$\mathrm{FeO}$ & 98.77 & 98.10 & 98.69 & 98.52 & 98.04 & 98.56 \\
$\mathrm{MnO}$ & 0.22 & 0.19 & 0.34 & 0.23 & 0.24 & 0.14 \\
$\mathrm{MgO}$ & 0.14 & 0.07 & 0.06 & 0.18 & 0.19 & 0.06 \\
$\mathrm{CaO}$ & 0.37 & 0.46 & 0.47 & 0.39 & 0.41 & 0.13 \\
\hline $\mathrm{Celkem}$ & 100.36 & 99.61 & 100.26 & 100.05 & 99.93 & 100.29 \\
\hline $\mathrm{Si}^{4+}$ & 0.005 & 0.006 & 0.003 & 0.004 & 0.003 & 0.002 \\
$\mathrm{Ti}^{4+}$ & 0.001 & 0.001 & 0.001 & 0.001 & 0.002 & 0.005 \\
$\mathrm{Al}^{3+}$ & 0.005 & 0.003 & 0.003 & 0.003 & 0.006 & 0.002 \\
$\mathrm{Cr}^{3+}$ & b.d. & b.d. & 0.001 & 0.001 & 0.002 & 0.007 \\
$\mathrm{Fe}^{2+}$ & 0.972 & 0.973 & 0.975 & 0.974 & 0.967 & 0.968 \\
$\mathrm{Mn}^{2+}$ & 0.002 & 0.002 & 0.003 & 0.002 & 0.002 & 0.001 \\
$\mathrm{Mg}^{2+}$ & 0.002 & 0.001 & 0.001 & 0.003 & 0.003 & 0.001 \\
$\mathrm{Ca}^{2+}$ & 0.005 & 0.006 & 0.006 & 0.005 & 0.005 & 0.002 \\
\hline $\mathrm{Catsum}^{2+}$ & 0.992 & 0.992 & 0.994 & 0.993 & 0.991 & 0.988 \\
\hline
\end{tabular}


Ni) byly detekovány jako príměsi ve vyredukovaném železe. Vysoký obsah fosforu a také fluoru ve struskových fázích či vyredukovaném kovu nelze vztahovat k vlastní hmotě moravanských pelosideritů, v nichž nebyly žádné fáze s obsahem $P$ a/nebo $F$ zjištěny (Dolníček et al. 2019), citovaní autoři však na rudní haldičce moravanského dolu nalezli $v$ asociaci $s$ pelosiderity i fosforitovou konkreci tvořenou karbonát-fluorapatitem s detritickou prríměsí. I z analýz jednotlivých úlomků použité rudy (tab. 1) je zcela zřejmé, že i fosforitové konkrece se dostaly do rudní vsázky, použité pro předmětnou buchlovskou tavbu železa.

Při porovnání se studií Dolníčka et al. (2020), jejímž předmětem bylo studium strusek a železa po přímé výrobě železa ve shodném typu pece z Mn-obohacené limonitové rudy, vzniklé větráním pelosideritů, můžeme konstatovat řadu shodných znaků. Nejnápadnějšími společnými znaky jsou sklovitý charakter strusek, minimální obsah krystalických struskových fází, značná heterogenita ve složení různých vzorků strusek a zvýšený obsah $\mathrm{Mn}$ ve sklovině i krystalických fázích. Kovová fáze má $v$ obou př́padech srovnatelně zvýšený obsah fosforu. Naproti tomu Ize konstatovat pestřejší fázové složení a vyšší obsah $\mathrm{Ca}$ a $\mathrm{Mg}$ ve struskách vzniklých při zpracování čerstvých (nezvětralých) pelosideritů (tato práce). Nepochybně je to způsobeno prítomností karbonátů $v$ nezvětralých rudách, vyznačujících se zvýšenými až vysokými obsahy obou prvků (viz Dolníček et al. 2019), které se během zvětrávání rozkládají a uvolněný $\mathrm{Ca}$ a $\mathrm{Mg}$ jsou, na rozdíl od Fe a Mn, odnášeny zvětrávacími roztoky pryč. Je zajímavé, že stejně se nechovala také síra, doložená v pelosideritech ve formě pyritu (Dolníček et al. 2019), která je rovněž obvykle vysoce mobilní v podmínkách supergeneze. Sklovina ze strusek z limonitů však obsahuje srovnatelné množství síry jako strusky z čerstvých pelosideritü; v kovovém železe vyredukovaném z limonitů byly navíc zjištěny i inkluze pyrhotinu (Dolníček et al. 2020). Konzervativní chování síry během supergeneze by bylo možno vysvětlit bud' sorpčními schopnostmi oxyhydroxidů železa (např. Bigham, Nordstrom 2000) jakožto hlavní složky limonitu, nebo její imobilizací ve zvětrávající rudě v podobě barytu (této možnosti by mohla nasvědčovat zřetelná korelace mezi zvýšenými obsahy $S$ a zvýšenými obsahy Ba $\vee$ některých analýzách skloviny, zjištěná $v$ obou diskutovaných datových souborech). $V$ prípadě vazby síry na Ba-sulfát ovšem nelze zcela vyloučit ani jeho primární původ v okolních flyšových horninách, případně je protí- najících karbonátových žilkách (srov. Novotný 2011; Uhlî́ et al. 2011; Vlasáková 2015), i když ve vzorcích pelosideritů a fosforitů z lokality Koryčanská cesta, použitých $\mathrm{k}$ předmětné tavbě železa, nebyl baryt zjištěn ani ve stopovém množství (Dolníček et al. 2019). Vzhledem k běžné přítomnosti kalcitu $v$ nezvětralých pelosideritech je logické, že pouhým vyžíháním rudy před tavbou nemohlo dojít k odstranění přitomné síry (oxidací pyritu vzniklý $\mathrm{SO}_{2}$ je totiž v prítomnosti volného $\mathrm{CaO}$, vzniklého termickým rozkladem kalcitu, fixován v podobě $\mathrm{CaSO}_{4}$; Dong et al. 2003), to by muselo následovat i loužení vyžíhané rudy ve vodě (srov. v minulosti používaná technologie úpravy beskydských pelosideritů; Roth, Matějka 1953).

Námi studované strusky jsou tvořeny převážně sklem, stejně jako $v$ případě strusek vzniklých při předchozí tavbě chřibských limonitů vzniklých větráním pelosideritů (Dolníček et al. 2020). Naproti tomu typické železářské strusky mají hemikrystalickou či krystalickou strukturu a jejich hlavními složkami jsou fayalit a wüstit, kdežto sklo, pokud je vůbec prítomno, bývá jen vedlejší komponentou (Bachman 1982; Pleiner 2000; Zmeškalová 2010; Svoboda 2014; Křivánek 2015). Možné přičiny skutečnosti, proč strusková tavenina nevykrystalizovala, podrobně diskutovali již Dolníček et al. (2020). V našem případě se Ize $s$ jejich závěry, vzhledem ke značné podobnosti klíčových hodnotících parametrů, v zásadě ztotožnit. $Z$ chemického složení skloviny vypočítané hodnoty indexu viskozity (v.i.; tab. 2) pro většinu analýz nevybočují z obvyklého intervalu uváděného pro historické strusky (0.5 - 1.0; Bachman 1982). Na druhou stranu je třeba poznamenat, že vedle chemismu je viskozita neprímo úměrná i teplotě strusky a také fakt, že se strusku během tavby nepodařilo odpíchnout, naznačuje její vyšší viskozitu. Druhým možným vysvětlením mohl být nevhodný teplotní režim při tavbě, jmenovitě kombinace př́liš vysoké teploty a následného prudkého ochlazení. K odhadu dosažené teploty je možné využít například chemického složení silikátové taveniny (strusky), pokud ho Ize aproximovat experimentálně proměřeným systémem, $v$ našem případě je však její chemismus př́liš složitý. Vhodným kandidátem pro posouzení teplotního režimu je však vyredukovaná kovová fáze. Dokonale kulovitý tvar kovových kapek uzavíraných ve sklovité strusce (obr. 3a, 6a), stejně jako dendritické formy vyloučenin nízkofosforového železa v kapkách, uložených $v$ jemnozrnné, fosforem bohatší eutektické směsi železa a schreibersitu (obr. 5f), jasně ukazují, že kov

Tabulka 10 Přiklady chemického složení kovového železa ze studovaných strusek. Obsahy prvků v hm. \%, hodnoty apfu jsou vypočitány na základ 1 atomu na vzorcovou jednotku. b.d. - pod mezí stanovitelnosti

\begin{tabular}{lrrrrrrrrrrrrrr}
\hline An. č & 1 & 2 & 3 & 4 & 5 & 6 & 7 & 8 & 9 & 10 & 11 & 12 & 13 & 14 \\
Vzorek & STR-9 & STR-9 & STR-9 & STR-9 & STR-10 & STR-6 & STR-12 & STR-7 & STR-8 & STR-12 & STR-11 & STR-11 STR-10 STR-10 \\
\hline Fe & 100.14 & 99.49 & 98.97 & 99.35 & 99.17 & 99.45 & 98.51 & 98.16 & 94.28 & 90.51 & 88.34 & 88.43 & 86.33 & 85.85 \\
Co & 0.08 & 0.08 & 0.10 & b.d. & 0.08 & 0.07 & 0.09 & 0.08 & 0.08 & 0.07 & 0.06 & 0.06 & 0.08 & 0.06 \\
Ca & 0.10 & 0.49 & 0.59 & 0.61 & b.d. & b.d. & b.d. & b.d. & b.d. & b.d. & b.d. & b.d. & b.d. & b.d. \\
S & b.d. & b.d. & b.d. & b.d. & b.d. & b.d. & b.d. & b.d. & 0.18 & 0.16 & 0.55 & 0.53 & 0.08 & 0.06 \\
P & b.d. & b.d. & b.d. & b.d. & 0.41 & 0.83 & 1.60 & 1.95 & 6.21 & 9.10 & 10.87 & 10.96 & 13.38 & 14.52 \\
\hline Celkem & 100.32 & 100.06 & 99.66 & 99.96 & 99.66 & 100.35 & 100.20 & 100.19 & 100.75 & 99.84 & 99.82 & 99.98 & 99.87 & 100.49 \\
\hline Fe & 0.998 & 0.992 & 0.991 & 0.992 & 0.992 & 0.985 & 0.971 & 0.965 & 0.891 & 0.844 & 0.811 & 0.810 & 0.780 & 0.765 \\
Co & 0.001 & 0.001 & 0.001 & b.d. & 0.001 & 0.001 & 0.001 & 0.001 & 0.001 & 0.001 & 0.001 & 0.001 & 0.001 & 0.001 \\
Ca & 0.001 & 0.007 & 0.008 & 0.008 & b.d. & b.d. & b.d. & b.d. & b.d. & b.d. & b.d. & b.d. & b.d. & b.d. \\
S & b.d. & b.d. & b.d. & b.d. & b.d. & b.d. & b.d. & b.d. & 0.003 & 0.003 & 0.009 & 0.008 & 0.001 & 0.001 \\
P & b.d. & b.d. & b.d. & b.d. & 0.007 & 0.015 & 0.028 & 0.035 & 0.106 & 0.153 & 0.180 & 0.181 & 0.218 & 0.233 \\
\hline
\end{tabular}


byl původně v tekutém stavu. Chemické složení kovové fáze můžeme, podobně jako v případě vzorků studovaných Dolníčkem et al. (2020), velmi dobře aproximovat systémem Fe-P. Stanovenému minimálnímu zjištěnému obsahu $\mathrm{P}$ v celé kovové kapce (cca $1.5 \mathrm{hm}$. \%) odpovídá ve fázovém diagramu Okamota (1990) nejvyšší teplota začátku krystalizace kovové taveniny při cca $1490{ }^{\circ} \mathrm{C}$ (obr. 8). Naproti tomu nepravidelné a členité tvary částic bezfosforového železa přitomného v nístějové strusce vzorku STR-9 poukazují na to, že kov pravděpodobně nebyl v kapalném stavu, a že tedy teplota v nístěji nepřekročila bod tání čistého železa $\left(1538{ }^{\circ} \mathrm{C}\right.$; obr. 8). Na základě texturní charakteristiky a chemického složení kovové fáze můžeme tedy teplotu $v$ peci $v$ daném př́padě poměrně přesně lokalizovat $k$ hodnotě cca $1500^{\circ} \mathrm{C}$. $V$ železářských pecích pro prímou redukci je v nístěji obvykle dosahováno teplot $900-1300{ }^{\circ} \mathrm{C}$ (Pleiner 1969, 2000; Stránský et al. 2000), výjimečně i přes $1400{ }^{\circ} \mathrm{C}$ (Pleiner 2000). Je tedy zřejmé, že $v$ našem případě byla teplota $\checkmark$ peci skutečně vyšší, než je obvyklé. Vzhledem $\mathrm{k}$ tomu, že po ukončení tavby byla pec inned otevřena a nístějový slitek byl vylomen ven, je pravděpodobné, že vyšší pecní teplota v kombinaci s následným prudkým zchlazením obsahu pece mohly přispět $\mathrm{k}$ zachování skelného stavu strusky. Třetí možná přičina, proč nedošlo ke krystalizaci, mưže být zapříčiněna specifickým chemickým složením strusky. Dolníček et al. (2020) uvažují, že jako inhibitor krystalizace mohly působit zvýšené obsahy Mn. Jeho obsahy jsou $v$ porovnání $s$ typickými krystalickými železářskými struskami $\mathrm{i} v$ našem případě několikanásobně vyšší a jsou obdobné jako obsahy ve sklovině strusek studovaných Dolníčkem et al. (2020; viz obr. 4b). Na druhou stranu je třeba poznamenat, že jsou známy i krysta-

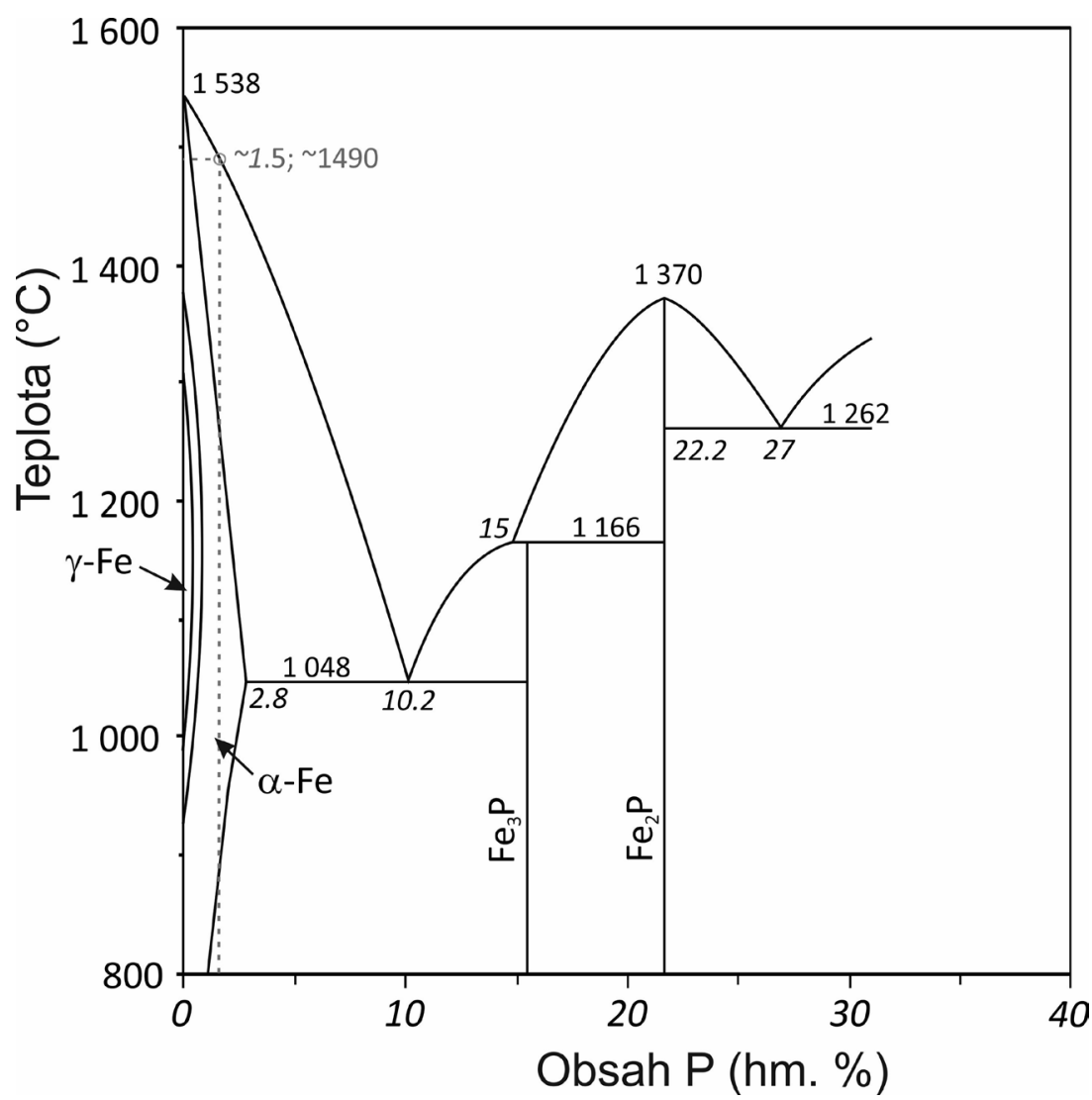

Obr. 8 Fázový diagram systému Fe-P (upraveno podle Okamota 1990) s ilustraci odvození teplot diskutovaných v textu (světle šedou barvou). lické strusky s ještě vyšším obsahem Mn (K. Malý, osobní sdělení 2021). Je zajímavé, že ani zvýšené obsahy Ca v tavenině (obr. 4d) nepřispěly ke zlepšení krystalizační schopnosti strusky. Naproti tomu se zdá, že pozitivně na krystalizační schopnost strusky pưsobily zvýšené koncentrace Mg, nebot' všechny zjištěné krystalické fáze, schopné vázat do své struktury $\mathrm{Mg}$, mají obsahy $\mathrm{Mg}$ značně zvýšené. To se týká i různých koexistujících fází (pyroxeny, olivíny) přitomných v prostorově omezených polyfázových (hemi)krystalických doménách, takže můžeme předpokládat zvýšený obsah Mg v „protolitu“ těchto domén jako celku a ne uplatnění procesu významnějšího selektivního „vychytáváni“" Mg rostoucí krystalickou fází $z$ velkého objemu okolní taveniny. Velmi pravděpodobně tyto ostře omezené (hemi)krystalické domény představují termicky metamorfované úlomky rudy původně bohaté Mg-karbonáty (Mg-bohatý siderit, dolomit?). V souladu $\mathrm{s}$ touto interpretací je i morfologie přitomných krystalů fayalitu, kdy prítomnost izometrických až tlustě tabulkovitých individuí nasvědčuje pomalé krystalizaci při malých rychlostech chladnutí taveniny (většinou $40^{\circ} \mathrm{C} / \mathrm{h}$ a méně; Donaldson 1976).

Pozoruhodné jsou mikrosondou měřitelné obsahy $\mathrm{Ca}$ v kovovém železe z nístějové strusky STR-9, dosahující až $0.61 \mathrm{hm}$. \% (tab. 10). Jejich prítomnost neumíme uspokojivě vysvětlit. Za prvé může jít o submikroskopické inkluze cizí Ca-fáze uzavřené v železe, prípadně odmíšené při chladnutí kovu. Oldhamit (CaS) je nepravděpodobný ( $v$ peci byla přiliš nízká teplota na jeho vznik, také chybí síra jež byla při analýzách rovněž měřena), karbid vápníku také (přiliš nízká teplota na jeho vznik), kyslíkaté fáze rovněž (absence Al, Si a dalších prvků). Druhou možností je redukce Ca na kovový vápník, zde je problémem opět přiliš nízká teplota v peci (Adolf 2013; Krét 2013; Mu et al. 2018). Faktem zůstává, že kovová fáze $v$ tomto jediném vzorku vykazuje do značné míry anomální složení (vedle obsahu $\mathrm{Ca}$ zejména úplnou absenci $\mathrm{P}$ ). Obsahy Co jsou však shodné s ostatními kovovými částicemi pocházejícími z dané tavby, takže pravděpodobně nelze uvažovat ani o možnosti, že jde o nějakou kontaminaci moderním kovem (kovového vápníku či slitin vápníku se v současnosti někdy používá k odstranění stop kyslíku z roztavených ocelí; Adolf 2013).

Lem okolo jedné kovové kapky, tvořený fosfátem Fe a wüstitem, je dokladem částečného odfosfoření vyredukovaného kovu působením $\mathrm{FeO}$ (Adolf 2013). FeO nezbytný pro tento proces nepocházel z okolní silikátové strusky, vzhledem $\mathrm{k}$ jeho všeobecné vzácnosti ve studovaných struskách, a také nízkým obsahům dalších „struskových“ prvků (Al, Si, Ca, alkálie) v chemismu fází tvořících lem. Je naopak pravděpodobné, že $\mathrm{FeO}$ vznikl sekundárně, částečnou oxidací této železné kapky. Oxidační charakter atmosféry $v$ peci je pouze $v$ blízkém okolí zaústění dyzny (Krét 2013), takže je zřejmé, že se daná kapka $v$ době ukončení tavby nacházela 
v dosahu oxidační atmosféry, tedy dmýchaného vzduchu.

Z pohledu výtěžnosti finálního „výrobku“, tedy vyredukovaného kovu, je třeba hodnotit tuto experimentální tavbu jako jednoznačně neúspěšnou, nebot' nístějový struskový slitek obsahoval pouze stopy vyredukovaného železa. Příčinu je třeba hledat v nízké kovnatosti použité rudy (tab. 1; srov. též Dolníček et al. 2020). Na to ukazuje i relativně častá přítomnost neroztavených reliktů křemene ve studovaných struskách a prítomnost jen velmi malého množství wüstitu. Zde je potřeba si uvědomit, že každé jedno hmotnostní procento $\mathrm{SiO}_{2}$, prítomné v rudě, váže během hutnického procesu $2.4 \mathrm{hm}$. \% FeO do struktury hlavní silikátové struskové fáze (fayalitu), z níž již není v podmínkách prímé redukce bez použití dalších přísad možno železo vyredukovat. Jinými slovy při obsahu $\mathrm{SiO}_{2}$ $v$ rudě $30 \mathrm{hm}$. \% a více již nelze přímou redukcí žádné železo vyrobit (viz též Barák 1995). Klíčový je tedy pečlivý výběr rudy a její předběžná úprava, tak, aby bylo odstraněno co nejvíce znečišt'ujících príměsí. $V$ našem případě byly obsahy balastních složek tak vysoké, že „nepomohly" ani nadstandardně vysoké obsahy $\mathrm{Ca}$ a $\mathrm{Mg}$ v rudě, které při redukční tavbě nahrazují Fe ve struktuře vznikajících struskových silikátů a přispívají tak ke zvýšení výtěžku kovu (Hošek 2003).

Porovnání nově získaných poznatků s historickými železářskými struskami z období 5. stol. př. n. I. až 15. století, kdy se na našem území železo vyrábělo prímou metodou, zpracovaných z oblasti Uherskohradišt'ska Křivánkem $(2009,2015)$ plně potvrzuje závěry, které jsme nastínili již v předchozím článku (Dolníček et al. 2020). Z pohledu fázového složení strusek Ize konstatovat většinou zásadní rozdíl, nebot' železářské strusky mají typicky obvyklé fayalit-wüstitové složení a jen minoritní zastoupení skloviny a případně i dalších fází (leucitu, pyroxenu). Značné rozdíly lze konstatovat i v chemickém složení jednotlivých struskových fází. Fayalit, pyroxeny i sklovina jsou ve srovnávaných železářských struskách výrazně chudší manganem (obr. 4b,6,7), sklovina většinou i hořčíkem (obr. 4f). Historické strusky jsou také výrazně chudši vápníkem, takže se v nich vůbec nevyskytuje dikalciumsilikát, melilit a Ca-bohaté živce. Chybí v nich také apatit, K-živec a kalsilit. Sklovina těchto železářských strusek bývá naopak výrazněji nabohacena nekompatibilními prvky - hliníkem, alkáliemi a fosforem (obr. 4c,e,g). Kovová fáze je tvořena většinou čistým železem, ojediněle byly zaznamenány i kapky „litiny“. Fosfor nebyl u části vzorků $v$ kovové fázi analyzován; v těchto príipadech však absence mikroskopicky patrných texturních nehomogenit, stejně jako analytické sumy blízké $100 \%$ vylučují jeho prítomnost ve vyšších koncentracích. $Z$ uvedeného vyplývá, že využití místních pelosideritových železných rud (a z nich zvětráváním vzniklých limonitů) nelze v dané oblasti na základě provedených rozborů v období, kdy se železo vyrábělo prímou metodou, potvrdit.

I ve srovnání s železářskými struskami z jiných oblastí či z dalších experimentálních taveb (např. Zmeškalová 2010; Svoboda 2014) Ize konstatovat př́tomnost výše zmíněných významných rozdílů. Výjimečně širokou, možno říci až extrémní variabilitu ve fázovém složení strusek a chemismu olivínů, pyroxenů a živců Ize jednoznačně vztáhnout ke specifickému chemickému složení a kompoziční heterogenitě vstupní rudní suroviny. $\mathrm{V}$ důsledku vysokého obsahu Ca se složení některých domén bliží až složení novodobých vysokopecních strusek (přítomnost melilitu, dikalciumsilikátu a dalších Ca-silikátů; srov. Gregerová 1999).

\section{Závěr}

Pro experimentální tavbu železa $v$ replice šachtové nadzemní pece, realizované v roce 2019 na hradě Buchlově, byla použita nezvětralá pelosideritová železná ruda z lokality Moravany u Kyjova. Vzniklá pecní struska je tvořena prakticky jen sklovinou, jen ojedinělé malé domény obsahují i krystalické fáze, jejichž zastoupení je místo od místa velmi variabilní. Detailní studium chemického složení ukázalo také extrémní heterogenitu ve složení skla i silikátových fází. Sklovina obsahuje variabilní, často i značně zvýšené obsahy $\mathrm{Mn}, \mathrm{Ca}, \mathrm{Mg}$ a někdy i P či K. Složení olivínu široce kolísá mezi fayalitem, dikalciumsilikátem a tefroitem $\left(\mathrm{Fa}_{1-91} \mathrm{Fo}_{3-28} \mathrm{Te}_{2-45} \mathrm{DCS}_{1-52}\right)$. Složení vápenatých pyroxenů je rovněž značně variabilní $\left(\mathrm{Wo}_{37-60} \mathrm{Tsch}_{1-13} \mathrm{Ka}_{8-22} \mathrm{Fs}_{4-30} \mathrm{En}_{14-36}\right)$. Živce vykazují složení mezi ortoklasem a anortitem ( $\left.\mathrm{Or}_{2-82} A n_{9-91} A b_{5-19} \mathrm{Cn}_{0-2} \mathrm{Slw}_{0-2}\right)$, $v$ prírodních systémech neznámé. Málo zastoupenými komponentami jsou wüstit, melilit (åkermanit s 1 - 6 mol. $\%$ gehlenitové komponenty), leucit, kalsilit, lokálně i apatit a nepojmenovaná fáze $\mathrm{Ca}_{2} \mathrm{Al}_{2} \mathrm{Si}_{3} \mathrm{O}_{11}$. Vyredukované železo je rovněž heterogenní, bohaté fosforem. Fázové složení strusky se výrazně liší od typických železářských strusek. Příčinu je možné spatřovat jednak $v$ anomálním chemickém složení vsázky, v př́liš vysoké teplotě při tavbě (fázové vztahy v kovovém železe nasvědčují teplotám kolem $1500^{\circ} \mathrm{C}$ ) v kombinaci s rychlým ochlazením obsahu pece po ukončení tavby a pravděpodobně i vyšší viskozitě strusky. Jak fázové složení strusky, tak chemické složení struskových fází i vyredukovaného kovu se výrazně liší od charakteristik historických železářských strusek Uherskohradišt'ska z období prímé výroby železa. Uvedená zjištění tedy nepodporují domněnku, že by místní pelosideritové železné rudy mohly být již $v$ této době využívány k výrobě železa.

\section{Poděkování}

Práce na dané problematice byly finančně podpořeny Ministerstvem kultury $C \check{R} v$ rámci institucionálního financování dlouhodobého koncepčního rozvoje výzkumné organizace Národní muzeum (DKRVO 2019-2023/1.III.c, 00023272). K. Malému (Muzeum Vysočiny Jihlava) a J. Kapustovi (Univerzita Palackého Olomouc) jsme zavázáni za recenzní pripomínky, které pomohly vylepšit pưvodní verzi rukopisu.

\section{Literatura}

Adolf Z (2013) Teorie procesů při výrobě železa a oceli, část II - teorie ocelářských pochodů. VŠB - TU Ostrava

BACHMANN HG (1982) The identification of slags from archaeological sites. Occasional publication No. 6, Institute of Archeology, London

BARÁK M (1995) Experimentální výroba železa v peci z doby Velké Moravy. MS, diplomová práce, VUT Brno

BIGHAM JM, NoRdSTROM DK (2000): Iron and aluminum hydroxysulfates from acid sulfate waters, in sulfate minerals: crystallography, geochemistry and environmental significance. Rev Mineral Geochem 40: 303-350

DeEr WA, Howie RA, Zussman J (1963) Rock-forming minerals: Feldspars, vol. 4A. Geological Society of London

Dolniček Z, Kandrnál L, Ulmanová J, VRatislavská E, Hojač P (2019) Historická těžba pelosideritů na lokalitě Koryčanská cesta u Moravan, jižní Chřiby. Bull Mineral Petrolog 27: 304-316 
Dolniček Z, Kandrnál L, Ulmanová J, Vratislavská E, Hojač P (2020) Strusky a železo z experimentální tavby železa realizované na hradě Buchlově (jv. Chřiby) v roce 2018. Bull Mineral Petrolog 28(1): 58-68

DONALDSON CH (1976) An experimental investigation of olivine morphology. Contrib Mineral Petrol 57: 187-195

Dong XW, Wang H, LIU H, QIN JR (2003) Study on $\mathrm{SO}_{2}$ emission under various atmospheres during coal combustion. Acta Sci Circumst 23: 322-326

Gregerová M (1999) Petrografie technických hmot. MU Brno

HošEk J (2003) Metalografie ve službách archeologie. Archeologický ústav AV ČR Praha a Technická univerzita $v$ Liberci

KRÉT J (2013) Základy teorie a technologie výroby železa a oceli, část železářství. VŠB - TU Ostrava

KŘIVÁNEK J (2009) Inventarizace výskytů historických železářských strusek v oblasti Chřibů. MS, bakalářská práce, PřF UP Olomouc

KŘIVÁNEK J (2015) Mineralogické studium artefaktů po železářské výrobě z vybraných lokalit $v$ okolí Starého Města u Uherského Hradiště. MS, diplomová práce, PřF UP Olomouc

Morimoto N, Fabries J, Ferguson AK, Ginzburg IV, Ross M, Seifert FA, Zussman J (1989) Nomenclature of pyroxenes. Can Mineral 27: 143-156

Mu H, Zhang T, Fruehan RJ, Webler BA (2018) Reduction of $\mathrm{CaO}$ and $\mathrm{MgO}$ slag components by $\mathrm{Al}$ in liquid $\mathrm{Fe}$. Metallurg Material Transact B 49(4): 1665-1674

Novotný P (2011) Celestin z okolí statku Zikmundov u Buchlovic. Zpr Vlast Muz Olom 301: 92-97
Окамото H (1990) The Fe-P (iron-phosphorus) system. Bull Alloy Phase Diagr 11(4): 404-412

PleineR R (1969) Experimental smelting of steel in early Medieval furnaces. Pam Archeol 60: 458-487

Pleiner R (2000) Iron in archeology: The European bloomery smelters. Archeologický ústav AV ČR, Praha

POUCHOU JL, PICHOIR F (1985) "PAP" ( $\varphi \rho Z)$ procedure for improved quantitative microanalysis. In: ARMSTRONG JT (ed.) Microbeam Analysis: 104-106. San Francisco Press, San Francisco

Rотн Z, MATĚJKA A (1953) Pelosiderity Moravskoslezských Beskyd. Geotechnica 16: 1-112

Stránský K, Souchopová V, Merta J (2000) Rekonstrukce pochodů př́mé výroby železa z rud. Archeol techn 11: 12-21

SvoвodA R (2014) Charakterizace železářských strusek z pokusné tavby realizované Technickým muzeem $\mathrm{v}$ Brně v r. 2012. MS, bakalářská práce, PřF UP Olomouc

Uhliǩ D, DolničEK Z, KolBinger D (2011) Rekognoskace a šlichová prospekce terénních pozůstatků po možné těžbě nerostných surovin na Hostýně (Hostýnské vrchy). Acta Mus Moraviae, Sci geol 96(1): 47-60

VLASÁKOVÁ J (2015) Hydrotermální mineralizace v západní části Chřibů. MS, bakalářská práce, PřF UP Olomouc

ZMEŠKALOVÁ B. (2010) Mineralogické studium artefaktů po železářské výrobě v okolí Bystřice pod Hostýnem. MS, diplomová práce, PřF UP Olomouc 